\title{
Filosofia como forma de vida: o embate com o ceticismo moderno
}

\author{
Rogério Lopes*
}

Resumo: O objetivo deste artigo é mostrar que o modo como Pascal reage à tentativa de Montaigne de retomada da filosofia como forma de vida a partir de uma releitura de certos elementos da tradição cética terá um impacto considerável no modo como o próprio Nietzsche, mais de dois séculos depois, procura retomar este mesmo projeto em suas obras do período intermediário (seção III). Segundo o diagnóstico de Nietzsche, a crise do cristianismo no início da modernidade não significou o desenvolvimento de uma vida contemplativa emancipada das ilusões religiosas, mas a degradação, para não dizer a supressão pura e simples, do ideal da vida contemplativa e a imersão no ativismo moderno ( $c f$. GC 359, ABM 58). A conhecida trilogia consagrada aos espíritos livres é em grande medida uma tentativa de se contrapor a essa tendência e recuperar um sentido não religioso da vida contemplativa no improvável contexto da sociedade burguesa da segunda metade do século XIX. O que tentarei mostrar é que partir de Aurora, Pascal se converterá em seu mais ilustre oponente. Mas inicialmente, (I) apresento o modo como Montaigne transforma a herança do ceticismo antigo, e na sequência (II) ofereço uma exposição de como Pascal reage à sua própria época, em especial ao projeto de retomada do ideal de vida contemplativa sem a tutela do cristianismo, projeto este que encontra em Montaigne seu principal representante.

Palavras-chave: ceticismo - vida contemplativa - Montaigne Pascal - integridade intelectual.

\footnotetext{
*Professor do Departamento de Filosofia da Universidade Federal de Minas Gerais, Brasil.

Correio eletrônico: roganlopes@gmail.com
} 
Lopes, R.

\section{A releitura do ceticismo antigo por Montaigne}

A forma de vida filosófica proposta por Montaigne empresta dois elementos centrais do ceticismo antigo: o compromisso com a integridade intelectual, que o ceticismo acadêmico preserva da imagem estóica do sábio, e o valor terapêutico da ataraxia, enfatizado pela tradição pirrônica. Podemos dizer que o primeiro corresponde à motivação ética para a suspensão do juízo, enquanto o segundo constitui sua motivação terapêutica ( $c f$. Sexto Empírico, Hipotiposes Pirrônicas, §§232-233). Em Montaigne parece não haver incompatibilidade na tentativa de promover simultaneamente ambos os valores. Mas há, quando comparado com os céticos antigos, uma atitude mais cautelosa e pessimista em relação à nossa capacidade de realizá-los plenamente. Esta atitude de desconfiança se funda em pressupostos antropológicos distintos dos pressupostos pagãos. $\mathrm{O}$ cético antigo parece ignorar que haja uma dificuldade envolvida na suspensão do juízo: se há uma equipolência na argumentação seguese a suspensão (inicialmente de forma involuntária, e depois como resultado de uma prática dialética). Na modernidade esta passagem do ceticismo epistemológico para o ceticismo psicológico será contestada pela maioria dos filósofos ${ }^{1}$. Além da dificuldade psicológica posta pela suspensão, há ainda a questão de sua desejabilidade. Com o desenvolvimento do ceticismo metódico na modernidade surge a possibilidade real de uma ciência orientada exclusivamente pelos fenômenos, algo que entre os antigos permanece incerto. $\mathrm{Na}$ perspectiva do ceticismo metódico o objetivo da suspensão é criar as condições ideais para a pesquisa da verdade. A atitude suspensiva é provisória, destinada a corrigir a mente e a vontade, a eliminar não apenas as crenças adquiridas através de métodos epistemicamente

1 Esta é uma tese polêmica em relação à história do ceticismo moderno. Maia Neto, 1995, 2005 considera esta tese inválida para o modelo fideísta de apropriação do ceticismo pirrônico (Montaigne e seus seguidores, Charron e La Mothe Le Vayer). Para uma defesa da tese de que não há suspensão do juízo no ceticismo moderno $c f$. Brahami, 2001 e Giocanti, 2001.

126 | Cad. Nietzsche, Guarulhos/Porto Seguro, v.38, n.3, p. 125-180, setembro/dezembro, 2017. 
não confiáveis como os vícios que se implantaram na alma em função dos maus hábitos de pensamento. O ceticismo metódico é mitigado e construtivo; ele recorre à crítica cética para cultivar no espírito as virtudes epistêmicas necessárias para que o agente cognitivo possa ter êxito na investigação do mundo empírico ou fenomênico.

O uso metódico do ceticismo surge a partir de uma analogia com a apropriação fideísta de argumentos céticos, que o antecede cronologicamente ${ }^{2}$. Diferentemente do que ocorria no uso de argumentos do ceticismo pirrônico para a defesa do critério católico para a fixação do conteúdo doutrinário da fé cristã (como encontramos em Erasmo; sobre isso, $c f$. Popkin, 2000), esta segunda modalidade de apropriação fideísta do ceticismo antigo é sugerida por Montaigne em sua "Apologia de Raymond Sebond" em apoio à sua tese de que o ceticismo pirrônico não apenas é compatível, como francamente favorável à fé cristã. Os argumentos céticos eliminam as crenças supersticiosas da alma e os vícios resultantes de sua atitude dogmática, tornando-a receptiva ao acolhimento da graça. O ceticismo fideísta pode ser utilizado neste sentido como uma preambula fidei ${ }^{3}$.

Esta apropriação do ceticismo fideísta tem sua contrapartida no âmbito da reflexão epistemológica. $\mathrm{O}$ uso de argumentos céticos é necessário para que possamos recuperar a integridade da faculdade de julgar. Aqui não se trata tão somente de substituir crenças falsas por crenças verdadeiras, mas de produzir uma reforma da mente pela substituição paulatina de vícios por virtudes epistêmicas, ou

2 Cf. Popkin, 1996.

3 Este uso apologético do ceticismo encontra-se formulado programaticamente na seguinte passagem da "Apologia de Raymond Sebond": "[A] Não há na imaginação humana nada que tenha tanta verossimilhança e utilidade [Montaigne se refere ao ceticismo pirrônico]. Ela apresenta o homem nu e vazio, reconhecendo sua fraqueza natural, apropriado para receber do alto uma força externa, desguarnecido de ciência humana e portanto mais apto para alojar em si a divina, anulando seu próprio julgamento a fim de dar mais espaço para a fé; [C] nem descrendo [A] nem estabelecendo algum dogma contra as observâncias comuns; humilde, obediente, disciplinável, zeloso; inimigo jurado da heresia e consequentemente isentando-se das ideias irreligiosas e vãs introduzidas pelas falsas seitas. [B] É uma tabula rasa preparada para assumir pelo dedo de Deus as formas que a este aprouver nela gravar" (Montaigne, II, 12, 2000, p. 260).

Cad. Nietzsche, Guarulhos/Porto Seguro, v.38, n.3, p. 125-180, setembro/dezembro, 2017. | 127 
Lopes, R.

seja, de substituir os maus métodos de formação de crenças por métodos adequados, permitindo a ela diferenciar as instâncias que têm competência epistêmica das que não a têm e se emancipar das últimas. $\mathrm{O}$ arsenal de argumentos céticos deve restituir o intelecto ao seu estado original de inocência, para que a partir daí ele possa cultivar as virtudes que lhe permitirão formar crenças verdadeiras. Supõe-se aqui, em analogia com a antropologia bíblica, que nossa faculdade de julgar se afastou de sua condição epistêmica original, ao se submeter a instâncias que não dispõem de competência epistêmica (a autoridade nas suas diversas manifestações) ou ao se propor problemas que ultrapassam sua competência (as tradicionais questões metafísicas).

Bacon utiliza o ceticismo metódico como arma contra o conteúdo e o método da ciência antiga e propõe um novo modelo de ciência, que prescinde de uma fundamentação metafísica e que se contenta com a perspectiva fenomenista ${ }^{4}$. Em Descartes convivem dois usos

4 Bacon parece inspirar-se diretamente em Montaigne em sua crítica à doutrina acadêmica da acatalepsia, reconhecendo nela apenas uma função propedêutica ou terapêutica. Montaigne encerra seu ensaio "Dos coxos" com uma tese original acerca das motivações da atitude cética que terá ressonâncias tanto no prefácio como em alguns aforismos do Novum Organon de Bacon. Montaigne afirma o seguinte acerca de Carnéades e dos céticos em geral: "“'Ogni medaglia ha il suo riverso." Eis por que Clitômaco dizia antigamente que Carnéades havia superado os trabalhos de Hércules, por haver arrancado dos homens o consentimento, ou seja, a decisão e a leviandade. Essa fantasia de Carnéades, tão vigorosa, em minha opinião nasceu antigamente da impudência dos que fazem alarde de saber, e de sua desmesurada displicência [...] Assim aconteceu na escola filosófica: o orgulho dos que atribuíam ao espírito humano a capacidade de todas as coisas causou em outros, por despeito e por emulação, essa idéia de que ele não é capaz de coisa alguma. Uns fundamentam na ignorância esse mesmo extremismo que outros fundamentam na ciência - para que não se possa negar que o homem é imoderado em tudo e que ele não tem outra barreira que não a da dificuldade e incapacidade de ir além" (Montaigne, III, 11, 2001, pp. 376-377). Bacon adota uma posição semelhante à de Montaigne ao argumentar que o ceticismo antigo, partindo de razões sólidas, acabou por assumir uma posição extrema, igualmente danosa para a investigação, por ter sido contaminado pelo espírito contencioso que propunha combater. Na origem desta objeção encontra-se a ojeriza moderna pelas disputas dialéticas. Bacon é um precursor de Lange e Nietzsche com sua tese de que os filósofos pré-socráticos representam um justo meio entre duas posições extremas e de que eles teriam sido precursores na aplicação do método experimental: "Todos aqueles que ousaram proclamar a natureza como assunto exaurido para o conhecimento, por convicção, por vezo professoral ou por ostentação, infligiram grande dano tanto à filosofia quanto às ciências. Pois, fazendo valer a sua opinião, concorreram para interromper e extinguir as investigações. Tudo mais que hajam feito não

128 | Cad. Nietzsche, Guarulhos/Porto Seguro, v.38, n.3, p. 125-180, setembro/dezembro, 2017. 
distintos do ceticismo: o uso metódico, similar ao de Bacon e Gassendi; e o uso hiperbólico e metafísico, que coloca os argumentos céticos a serviço de uma intenção dogmática. Independente de suas inúmeras divergências filosóficas, há uma tese comum entre os adeptos e praticantes do ceticismo metódico: a atitude dogmática interrompe de forma precipitada a investigação frustrando sua finalidade, que é o estabelecimento da verdade; mas certas formas de ceticismo extremo podem conduzir ao mesmo resultado, na medida em que orientam seus adeptos a se retirarem da investigação e a se resignarem com a ignorância. A atitude correta deve ser investigativa; o alvo é a verdade, não a suspensão do juízo. Pascal irá explorar esta nova finalidade do ceticismo como uma arma contra o ideal da ataraxia, na medida em que ele reivindica para as questões da religião a mesma atitude de persistência na investigação que filósofos como Bacon e Descartes reivindicam para a pesquisa científica.

compensa o que nos outros corromperam e fizeram malograr. Mas os que se voltaram para caminhos opostos e asseveraram que nenhum saber é absolutamente seguro, venham suas opiniões dos antigos sofistas, da indecisão dos seus espíritos ou, ainda, de mente saturada de doutrinas, alegaram para isso razões dignas de respeito. Contudo, não deduziram suas afirmações de princípios verdadeiros e, levados pelo partido e pela afetação, foram longe demais. De outra parte, os antigos filósofos gregos, aqueles cujos escritos se perderam, colocaram-se, muito prudentemente, entre a arrogância de sobre tudo se poder pronunciar e o desespero da acatalepsia. Verberando com indignadas queixas as dificuldades da investigação e a obscuridade das coisas, como corcéis generosos que mordem o freio, perseveraram em seus propósitos e não se afastaram da procura dos segredos da natureza. Decidiram, assim parece, não debater a questão se algo pode ser conhecido, mas experimentá-lo" (Bacon, 1973, p. 11). Na continuação Bacon diz que o que faltou a estes filósofos foi a imposição de uma disciplina metódica, regras para amparar os sentidos e dirigir o intelecto. Veja que a descrição das opções filosóficas feita por Bacon retoma não apenas a censura de Montaigne, mas também uma passagem crucial dos Academica de Cícero ( $c f$. Cícero, Ac. II, §7). Bacon se posiciona em relação ao ceticismo nos aforismos XXXVII (ele assume que sua teoria dos ídolos é inspirada nos tropos céticos da suspensão, mas com um propósito construtivo); LXVII (Bacon retoma aqui a acusação de que as posições dogmática e cética expressam um duplo excesso. Ele reconhece que o ceticismo acadêmico é programaticamente correto, mas não cumpre o que promete: "a Nova Academia transformou a acatalepsia em dogma e dela fez profissão"); LXVIII (Bacon expressa aqui a analogia entre o uso terapêutico do ceticismo e o uso apologético: ambos têm como tarefa restituir a alma ao seu estado original de inocência; no caso do conhecimento, ausência de vícios epistêmicos; no caso da religião, ausência de vícios morais); CXXVI (Bacon opõe a doutrina da acatalepsia à doutrina da eucatalepsia, para marcar a diferença entre seu intuito investigativo em contraposição ao intuito suspensivo do ceticismo antigo).

Cad. Nietzsche, Guarulhos/Porto Seguro, v.38, n.3, p. 125-180, setembro/dezembro, 2017. | 129 
Lopes, R.

No que diz respeito ao valor terapêutico da suspensão, é preciso distinguir dois aspectos: a tranquilidade mental em questões de opinião e a moderação dos afetos. A tranquilidade mental é alcançada na medida em que o filósofo cético reconhece que há uma indecidibilidade entre as teorias concorrentes acerca da essência daquilo que aparece e se contenta com uma perspectiva puramente fenomênica sobre o mundo. A tranquilidade mental, segundo o relato de Sexto Empírico, é um estado no qual o cético é lançado de forma não intencional; é um resultado involuntário da suspensão. Só podemos conferir plausibilidade psicológica a este evento se supomos que o cético desenvolveu algo como uma indiferença em relação à questão mesma que o angustiava intelectualmente. $\mathrm{O}$ contentamento com o fenômeno elimina o estado de agitação interior da alma que buscava decidir sobre temas que superam suas capacidades cognitivas

O segundo ganho terapêutico reivindicado pela tradição pirrônica, relativo à moderação dos afetos, depende de um pressuposto cognitivista acerca das emoções: ao suspender o juízo sobre o valor último das coisas, o cético elimina o conteúdo cognitivo do afeto e o modera. Para o pirrônico, a intensidade de minha resposta afetiva depende diretamente da natureza de minhas crenças. A crença de que algo é um bem em si torna sua posse imperativa e sua perda insuportável. Portanto, esta crença determina o meu modo de responder afetivamente tanto à presença quanto à ausência de um objeto. E nos dois cenários as respostas afetivas tendem à imoderação. O caminho para a moderação consiste na suspensão do juízo acerca do valor dos objetos de desejo. Todo afeto remete a um juízo de valor, que é o seu componente cognitivo. O pressuposto de Sexto é de que nós temos controle sobre este componente cognitivo das emoções e podemos eliminá-lo na medida em que examinamos suas credenciais epistêmicas (Sexto, Hipotiposes, §12).

Embora Montaigne preserve as duas dimensões terapêuticas do ceticismo pirrônico, ele não espera uma reforma milagrosa da 
vida afetiva com a ajuda de argumentos suspensivos. Montaigne acolhe inteiramente a primeira dimensão terapêutica do ceticismo pirrônico, que é comum à orientação epicurista e tem como meta promover um desinteresse pelas questões últimas. Montaigne defende a legitimidade deste desinteresse recorrendo ao argumento de que uma decisão quanto a estas questões depende do auxílio divino (fideísmo). É justamente a posição fideísta que permite a Montaigne propor uma nova agenda filosófica, organizada em torno do interesse pelas coisas próximas e cotidianas, pela reflexão sobre o corpo, as práticas diárias, os hábitos alimentares, as questões sexuais, o convívio social, o benefício das viagens, a diversidade dos costumes, entre tantos outros temas. $\mathrm{O}$ interesse por estas questões concorre diretamente com o interesse pelas questões últimas, comum tanto à espiritualidade religiosa quanto à especulação metafísica. A disputa entre Montaigne e Pascal é, portanto, uma disputa também em torno daquilo que deve constituir a agenda filosófica.

O último Montaigne (Livro III dos Ensaios) se distancia do pressuposto intelectualista implícito no argumento de Sexto Empírico que sustenta a segunda ambição terapêutica do pirronismo. O resultado é uma visão bastante modesta da eficácia terapêutica dos argumentos filosóficos: ela é apenas relativa, depende de uma estratégia retórica adequada e varia de indivíduo para indivíduo. Esta é a posição que Nietzsche assume aos poucos, ao longo do período intermediário. Nenhuma conversão milagrosa, mas uma transição lenta e gradual de um estado a outro, de acordo com um método orientado por uma concepção realista da natureza das paixões e adaptado às necessidades de cada caso.

\section{O ataque de Pascal ao ideal de vida cético}

A posição moderada de Montaigne será explorada por Pascal em sua nova estratégia apologética, que tem entre seus objetivos expor 
Lopes, R.

a inviabilidade prática do pirronismo/epicurismo e do estoicismo, oposição esta que segundo o jansenista esgota as opções filosóficas pagãs. Pascal explora as transformações sofridas pelo ceticismo antigo em sua recepção moderna de modo a decretar seu fracasso existencial. Nietzsche não pode deixar de concordar que sob certos aspectos Pascal está com a razão. Ele intensifica sua leitura de Pascal por volta de 1880 e esta intensificação tem como resultado um progressivo afastamento da posição intelectualista moderada característica da trilogia formada pelos dois volumes de Humano, demasiado Humano.

Na Entretien avec $M$. de Saci Pascal expõe pela primeira vez seu projeto de uma nova apologética do cristianismo e defende a tese de que Montaigne poderia ser (malgré lui) um aliado nesta empreitada $^{5}$. O ceticismo epistemológico, reinterpretado em um arcabouço antropológico do cristianismo, pode ser um valioso aliado da fé, como arma para humilhar a razão. Mas para tanto é necessário mostrar a inviabilidade de sua contrapartida ética; não apenas o estoicismo, também o ceticismo como forma de vida sustenta-se igualmente no desconhecimento de nossa condição. A ataraxia, a indiferença e a integridade intelectual serão os alvos visados por Pascal. O compromisso com a busca da verdade, a motivação central para a suspensão do juízo no ceticismo metódico, não será visto por Pascal como um adversário, mas como um aliado em sua empreitada apologética. Este é um aspecto para o qual se tem chamado pouca atenção. E ele me parece fundamental, pois Pascal o mobiliza contra o ideal pirrônico da indiferença: esta indiferença seria incompatível com a alegada disposição investigativa do cético. A tarefa central da primeira parte da apologia consiste em mostrar, sem recorrer aos elementos do cristianismo, que a atitude de indiferença frente à questão do destino da alma é insustentável segundo parâmetros

5 Pascal, 1963, pp. 291-296. Cf. a leitura de Maia Neto, 1995, pp. 37-47.

132 | Cad. Nietzsche, Guarulhos/Porto Seguro, v.38, n.3, p. 125-180, setembro/dezembro, 2017. 
puramente humanos ${ }^{6} .0$ compromisso com a busca da verdade formará o núcleo do ceticismo heróico formulado por Nietzsche a partir de Aurora. Minha tese é que Nietzsche responde diretamente ao desafio proposto por Pascal. A reconciliação com a especulação em Nietzsche tem início nesta reação a Pascal: por que não apostar na opção inversa, ao invés de simplesmente suspender o juízo? Por que não apostar Deus está morto? O que implica exatamente esta aposta? Uma resposta possível seria: a necessidade de um novo tensionamento da alma, que independa dos mecanismos ilusórios que operavam no interior da concepção cristã representada por Pascal.

Uma questão que tem interessado aos intérpretes de Pascal é saber o que o levou a privilegiar um confronto historicamente assimétrico entre Epiteto e Montaigne ao invés de confrontar diretamente dois filósofos pagãos ou dois filósofos cristãos ${ }^{7}$.

6 Este é o ponto em que minha leitura diverge também de Maia Neto, 1995. A defesa da tese da insustentabilidade da atitude de indiferença frente às questões postas pela religião recorre certamente às evidências antropológicas de nossa miséria destacadas pelos argumentos do divertimento e do amor-próprio e aos pressupostos eudaimonista e teleológico herdados da teoria grega da ação. Mas isso não me parece resumir toda a posição de Pascal. Ele utiliza contra o libertino um argumento $a d$ hominem, na medida em que o desafia a se manter firme na investigação, na busca. A abertura para a investigação é a única atitude capaz de promover os valores epistêmicos, segundo os adeptos do ceticismo construtivo do início da modernidade. Pascal não vê razão para restringir a investigação ao âmbito daquilo que aparece. Este é o ponto de divergência em relação aos adeptos do ceticismo metódico. Os fragmentos LA 427 e 428 concedem um notável destaque a este aspecto do projeto apologético: "Antes de entrar nas provas da religião cristã, acho necessário representar a injustiça dos homens que vivem na indiferença de buscar a verdade de uma coisa que lhes é tão importante e que lhes diz respeito de tão perto" (Pascal, 2001, p. 172). A novidade da apologia pascaliana consiste em seu ponto de partida: ao invés de se propor a demonstrar uma tese, ela argumenta a favor da centralidade de um conjunto de problemas (da existência de Deus e do destino da alma) e insiste na tese de que nossa incapacidade epistêmica de apresentar uma solução para a questão (Pascal nega a possibilidade e a utilidade do projeto cartesiano de uma metafísica racional) não anula a sua urgência existencial (pretensão pirrônica). $O$ célebre argumento da aposta (LA 418) pretende mostrar que em meio à obscuridade que cerca estas questões a razão, através do cálculo de probabilidades, nos recomenda apostar na alternativa "Deus existe". A opção pelo ceticismo epistemológico é sinônimo de força, mas apenas relativamente à nossa atual condição, restrição ignorada pelo cético que desconhece o mito da queda. A opção pelo pirronismo, pela indiferença, é sinônimo de fraqueza. A descrença também pode ser sinal de impotência: "Ateísmo marca de força do espírito, mas só até certo ponto" (LA 157 (225)).

7 Para uma recensão das diversas posições $c f$. Maia Neto, 1995: pp. 37-47.

Cad. Nietzsche, Guarulhos/Porto Seguro, v.38, n.3, p. 125-180, setembro/dezembro, 2017. | 133 
Lopes, R.

Naturalmente, pode haver mais de uma razão para tanto. A Pascal interessa antes de tudo rever o modelo fideísta de apropriação do ceticismo. Esta é uma razão para que ele privilegie o confronto com Montaigne. A segunda razão é a presença de elementos epicuristas em Montaigne, elementos que serão ressaltados por Pascal para reforçar sua interpretação dicotômica das opções filosóficas. A escolha de Montaigne atende ainda a duas considerações de ordem estratégica. O filósofo francês apresenta uma versão do ceticismo no qual três motivações distintas procuram conviver, o que não é tão visível no ceticismo antigo: o compromisso ético com a integridade intelectual (associado ao ceticismo acadêmico); a motivação terapêutica na sua dupla vertente (como veto à curiosidade metafísica e como estratégia de moderação dos afetos mediante a eliminação de seu elemento cognitivo ou, no caso de Montaigne, através do método da diversão) e os germes do que será a motivação metódica (motivação que se tornará central nos contemporâneos de Pascal: Bacon, Gassendi e Descartes). Pascal tentará mostrar que estes valores não podem ser perseguidos simultaneamente, que há uma concorrência entre eles, e que os homens são incapazes em todo caso de fazer frente às suas diversas exigências. A segunda razão estratégica que leva Pascal a privilegiar um confronto com Montaigne é o fato, já mencionado acima, de em seus últimos ensaios ele se mostrar consideravelmente mais pessimista em relação à eficácia terapêutica de argumentos filosóficos. Este pessimismo se deixa constatar com especial clareza em sua reflexão sobre o tema da morte. Parece-me que a transição do método da preparação para o da diversão, que recebeu grande destaque na leitura de Villey, marca menos uma evolução de Montaigne do estoicismo para o pirronismo/epicurismo do que a redefinição de uma estratégia de cura filosófica resultante de uma aguda tomada de consciência dos limites da eficácia terapêutica do método usualmente recomendado pelos filósofos.

134 | Cad. Nietzsche, Guarulhos/Porto Seguro, v.38, n.3, p. 125-180, setembro/dezembro, 2017. 
O ensaio que tem como título "Da Diversão" (Ensaios, III, 4) nos surpreende com uma nova e original concepção de terapia filosófica. Afinal, Montaigne parece agora recusar o pressuposto subjacente a seu anterior otimismo em relação ao poder terapêutico da filosofia: de que basta expor o caráter infundado de nossas fantasias, representações e opiniões sobre as coisas para alterar o modo como respondemos afetivamente às mesmas ${ }^{8}$. A constatação de que nossas crenças morais estão fundamentadas em pressupostos epistemicamente não confiáveis não tem o efeito moderador sobre os afetos prometido pela terapia pirrônica. Este me parece o sentido do deslocamento do método psicologicamente otimista da preparação para o método mais realista da diversão. Este método se adequa melhor à condição humana. Ele reconhece o primado das paixões sobre as razões e sabe tirar proveito da futilidade e da vaidade constitutivas do homem. $\mathrm{O}$ reconhecimento do primado das paixões não exige a renúncia da pretensão terapêutica, mas apenas um ajuste de método e uma compreensão mais modesta de sua eficácia. Argumentos filosóficos moderam a intensidade dos afetos não porque exibem o caráter infundado de seu componente cognitivo, mas porque despertam na

80 método oposto, da preparação, é recomendado nos diversos ensaios do Livro I que tratam do tema da morte. O título de alguns deles já nos comunica sua orientação otimista: "Que o gosto dos bens e dos males depende em boa parte da opinião que temos deles" (I, 14); “Que filosofar é aprender morrer" (I, 20). A introdução do ensaio I, 14 coloca a questão em termos programáticos: "Os homens (diz uma antiga máxima grega) são atormentados pelas idéias que têm das coisas, e não pelas próprias coisas. Haveria um grande ponto ganho para o alívio de nossa miserável condição humana se pudéssemos estabelecer essa asserção como totalmente verdadeira. Pois, se os males só entraram em nós por nosso julgamento, parece que está em nosso poder desprezá-los ou transformá-los em bem” (Montaigne, I, 14, 2000, p. 73). A questão posta por Montaigne só é válida sob o pressuposto, que ele parece não mais compartilhar nos ensaios de maturidade, de que a eliminação do elemento cognitivo nos afetos (a crença de que bem e mal designam propriedades objetivas) é suficiente para pacificá-los. Outro pressuposto é o de que temos controle sobre este conteúdo cognitivo, sobre as crenças. Já nos ensaios do Livro II Montaigne parece ser da opinião de que dispomos de um controle apenas parcial sobre elas. A suspensão do assentimento é um ideal que não nos é dado realizar plenamente. $C f$. Montaigne, II, 12, 2000, p. 258: “Quem imaginar uma perpétua admissão de ignorância, um julgamento sem tendência e sem inclinação, em qualquer ocasião que possa ser, está imaginando o pirronismo. Expresso essa opinião tanto quanto posso, porque muitos a acham difícil de conceber; e mesmo os autores apresentam-na de forma um pouco obscura e diversa".

Cad. Nietzsche, Guarulhos/Porto Seguro, v.38, n.3, p. 125-180, setembro/dezembro, 2017. | 135 
Lopes, R.

alma afetos que fazem concorrência ao afeto atualmente dominante. O que decide em última instância é a estratégia retórica; se ela é ou não apropriada para o caso. Uma filosofia com pretensões terapêuticas deve ser retoricamente consciente. $\mathrm{O}$ novo método propõe menos uma renúncia do que um acordo entre os afetos ${ }^{9}$. Devemos combater um afeto com outro afeto, ou então dispersá-lo em uma pluralidade de afetos menos intensos, de modo a evitar a tirania das paixões ${ }^{10}$.

Se o método da diversão em Montaigne aponta para o fracasso, ou pelo menos para uma compreensão muito modesta das pretensões terapêuticas do ideal da vida cética, nas mãos de Pascal ele se converterá numa das principais peças para minar a segunda principal reivindicação do ceticismo, a da integridade intelectual. $\mathrm{O}$ pouco de tranquilidade de que somos capazes, nós o conseguimos através de uma estratégia de evasão, de fuga de si. O método da diversão em Montaigne é extraído de uma metáfora militar (dividir para vencer, dispersar a atenção do inimigo, não oferecer resistência direta, mas oblíqua e dissimulada, conceder terreno para avançar em outra parte). Aplicado à vida psíquica, o método recomenda que se exponha a alma a uma variedade de objetos para que ela se livre da tirania de uma única paixão. Em Pascal este método é interpretado como uma metáfora da condição humana, que traduz a incapacidade da alma de conhecer a si mesma e amar a si mesma. Pascal consegue este efeito ao articular os dois aspectos da dimensão terapêutica do pirronismo em um único: o uso de argumentos céticos para justificar o abandono

9 “A vingança é uma doce paixão, muito impressiva e natural; percebo-o bem, embora não tenha qualquer experiência. Recentemente, para desviar dela um jovem príncipe, não lhe fiquei dizendo que era preciso oferecer a face a quem vos esbofeteara a outra, por dever de caridade; nem fui evocarlhe os trágicos eventos que a poesia atribui a essa paixão. Deixei-a estar e ocupei-me em fazê-lo saborear a beleza de uma imagem oposta: a honra, o favor, a benevolência que ele conquistaria pela clemência e bondade; desviei-o para a ambição. Eis como se age" (Montaigne, III, 4, 2001, p. 74).

10 Se vossa afeição no amor é forte demais, dissipai-a, dizem; e dizem muito bem, pois amiúde experimentei isso, com proveito; desbaratai-a em desejos diversos, dos quais haja um regente e senhor, se quiserdes; mas, para que ele não vos domine e tiranize, enfraquecei-o, contende-o, dividindo-o e desviando-o (Idem, ibidem, p. 74).

136 | Cad. Nietzsche, Guarulhos/Porto Seguro, v.38, n.3, p. 125-180, setembro/dezembro, 2017. 
da agenda filosófica da metafísica e o uso destes argumentos para produzir uma moderação dos afetos.

A substituição da agenda filosófica, proposta pelo pirronismo e retomada por Montaigne e, numa outra direção, por Bacon, é legitimada com a ajuda do argumento pirrônico de que estas questões não podem ser decididas epistemicamente. A renúncia à curiosidade metafísica produz um estado de tranquilidade mental que permite, no caso de Montaigne, que o indivíduo se ocupe de questões que têm um impacto real sobre sua vida, no caso de Bacon, que seu interesse teórico se concentre no estudo dos fenômenos. $\mathrm{O}$ veto à curiosidade metafísica é motivado em Montaigne pelo ideal de uma vida boa e está fundamentado em argumentos fideístas; em Bacon ele é motivado pelo ideal de reforma das ciências e pela expectativa de que com esta reforma o homem se torne finalmente senhor da natureza; mas também no pressuposto de que o conhecimento dos objetos da metafísica ultrapassa nossa capacidade cognitiva; querer conhecê-los é sinal de presunção.

O método da diversão em Montaigne atende a outra necessidade, a de administrar a vida dos afetos com o auxílio de um método terapêutico mais realista do que o praticado tradicionalmente pela filosofia. Sua adoção é fundada em argumentos distintos daqueles utilizados para legitimar a adoção de uma agenda filosófica. Não se trata para Montaigne de uma entrega pura e simples às paixões, mas do reconhecimento de que nem sempre argumentos estritamente racionais são capazes de fazer frente aos seus assaltos. Pascal, no entanto, aproveita esta deixa e promove um ataque agressivo ao ideal da ataraxia, sugerindo que é por se entregar ao divertimento que o pirrônico pode abraçar sua agenda filosófica em detrimento das questões que realmente interessam: o destino da alma e a existência de Deus. $O$ método proposto por Montaigne para dispersar as paixões tirânicas é reinterpretado como uma capitulação diante das paixões ${ }^{11}$.

11 Cf. Pascal, 2001, p. 155: LA 407 (465): “Os estóicos dizem: entrai dentro de vós mesmos, é aí 
Lopes, R.

Pascal mistura propositadamente dois debates: o debate em torno da legitimidade da nova agenda filosófica proposta por Montaigne e o debate acerca do melhor método de lidar com os afetos ${ }^{12}$. $O$ jansenista dispõe, no entanto, de um argumento inovador em relação à tese psicológica da diversão que permite a ele interpretá-la em um sentido que favoreça seu intuito apologético (ver abaixo o item c da reconstrução do argumento da diversão por Pascal). Esta transformação segue alguns passos que tentarei reconstruir brevemente. $\mathrm{O}$ argumento geral pode ser esquematizado nos seguintes pontos:

1. O compromisso com a integridade intelectual tem sua melhor expressão na disposição de permanecer na investigação. Esta disposição está em contradição com a busca da ataraxia através da suspensão do assentimento. Portanto, a indiferença frente às questões postas pela religião não concorda com as exigências da consciência intelectual. A exigência de permanecer na investigação concorda, por sua vez, com o imperativo da religião cristã de buscar Deus ${ }^{13}$. A religião cristã não prega o

que encontrareis o repouso. $\mathrm{E}$ isso não é verdade. Os outros dizem: saí fora e procurai a felicidade numa diversão. E isso não é verdade"; p. 156: LA 410 (413) "Essa guerra interior da razão contra as paixões fez com que aqueles que queriam ter a paz se dividissem em duas seitas. Uns quiseram renunciar às paixões e tornar-se deuses, os outros quiseram renunciar à razão e tornar-se animais brutos [...] Mas não o puderam, nem uns nem outros, e a razão sempre permanece a acusar a baixeza e a injustiça das paixões e a perturbar o repouso daqueles que a elas se abandonam. E as paixões estão sempre vivas naqueles que a elas querem renunciar".

12 LA 414 (171): "Miséria. A única coisa que nos consola de nossas misérias é a diversão. E no entanto é a maior de nossas misérias. Porque é ela que nos impede principalmente de pensar em nós e que nos põe a perder insensivelmente. Sem ela ficaríamos entediados, e esse tédio nos levaria a buscar um meio mais sólido de sair dele, mas a diversão nos entretém e nos faz chegar insensivelmente à morte" (Idem, p. 157).

13 Por isso Pascal insiste na tese de que só existem três tipos de pessoas: as razoáveis e felizes; as razoáveis e infelizes; as loucas e infelizes ( $c f$. LA 160). A razoabilidade é o máximo que se pode exigir do homem: a posição jansenista de Pascal define os limites da apologética e também os limites da participação humana na conversão própria ou alheia a partir deste princípio da razoabilidade, que é traduzido no compromisso sincero com a busca. Não se pode exigir do homem que ele creia, mas que ele se empenhe na busca. Este empenho exige uma atitude de submissão, claro. Mas antes que esta exigência propriamente cristã seja posta, ou seja, antes que Pascal diga a seu leitor que

138 | Cad. Nietzsche, Guarulhos/Porto Seguro, v.38, n.3, p. 125-180, setembro/dezembro, 2017. 
desprezo pela integridade intelectual, mas o reconhecimento da incapacidade humana de fazer frente às suas exigências.

2. A vida que se caracteriza pela busca da verdade no horizonte de ceticismo epistemológico não pode ser descrita como uma vida boa, mas como um sinal seguro da miséria da condição humana, pois o fim de toda investigação é a verdade. Contentarse com a busca é contentar-se com pouco, é entregar-se ao divertimento. $\mathrm{O}$ pressuposto eudaimônico, que a tradição cristã assume da antropologia pagã, é essencial para que Pascal possa sustentar sua visão da condição humana como uma condição contraditória e paradoxal. Não temos a verdade, mas não podemos deixar de buscá-la; não somos capazes de atingir o bem, mas não podemos deixar de nos relacionar com uma idéia de bem ${ }^{14}$.

3. O homem encontra-se numa condição tal, que nele toda pretensão à correção intelectual e ao conhecimento de si que não conduzam à consciência de sua própria miséria é fruto da impostura e da mentira ${ }^{15}$. Para provar esta última tese Pascal

o cristianismo exige a renúncia à integridade intelectual, ele argumenta ad hominem: a defesa da tese da insustentabilidade da atitude de indiferença não apela ainda para a máquina, o autômato. Este é um segundo passo, que Pascal recomenda após vencer o primeiro obstáculo, o da indiferença. Este segundo passo, o da submissão ("Il faut s'abêtir"), é um non sequitur em relação ao primeiro. Um non sequitur lógico, mas não necessariamente psicológico. Pascal conta poder conduzir seu leitor a uma atitude de perplexidade e mesmo de desespero lançando mão de argumentos fundados exclusivamente na razão e na experiência, para prepará-lo psicologicamente para este passo extremo.

14 Pascal explora este ponto em diversos fragmentos. $\mathrm{O}$ argumento de Pascal é simples: todo homem age em última instância visando a sua própria felicidade, e isso à revelia de todas as evidências empíricas que demonstram o fracasso desta empreitada como regra que não comporta exceção. Que ele seja obrigado a persistir em seu intento é sinal inequívoco de que este impulso é o que nos restou de nossa antiga condição. Cf. Pascal, 2001, pp. 59-60, LA 148 (425). O fragmento LA 117 (409) expressa esta tese através de uma imagem forte, a do rei deposto: "Pois quem se acha infeliz por não ser rei a não ser um rei deposto?" (Idem, p. 40).

15 Impostura e mentira da qual não podemos em última instância escapar. Pascal extrai esta consequência extrema através do exame dos paradoxos do amor-próprio. O auto-engano e a impostura são psicológica e socialmente necessários; sem a mentira e o engano mútuos não poderíamos conviver nem com o outro nem conosco mesmos. Toda tentativa de autoconhecimento leva ao desprezo de si. ( $c f$. Pascal, 2001, pp. 422-425, LA 978 (100)). O último parágrafo deste fragmento foi destacado por Nietzsche

Cad. Nietzsche, Guarulhos/Porto Seguro, v.38, n.3, p. 125-180, setembro/dezembro, 2017. | 139 
Lopes, R.

\title{
retoma o método da diversão de Montaigne e o traduz na tese do divertimento. Sugiro uma nova esquematização do argumento de Pascal de acordo com os seguintes $\operatorname{passos}^{16}$ :
}

\author{
a) toda atividade humana pode ser reduzida ao modelo do \\ divertimento, na medida em que ela não é orientada para um \\ fim racional, ou seja, um fim que de fato pudesse contribuir \\ efetivamente para a felicidade humana. Todos os fins das ações \\ humanas remetem à autoencenação e à vaidade, ao desejo de \\ evasão de si. Isso vale para as atividades políticas, mas também \\ para as atividades intelectuais ${ }^{17}$;
}

em sua edição alemã dos Pensamentos com um risco na margem direita. Pascal, 1865, II, p. 51:

"Der Mensch ist also nur Täuschung, Lug und Trug für sich selbst und in seinen Beziehungen zu Andern. Er will nicht, dass man ihm die Wahrheit sage; er vermeidet es, sie Andern zu sagen; und alle diese Fehler, die der Vernunft und Gerechtigkeit so zuwiderlaufen, haben eine natürliche Wurzel in seinem Herzen". ("O homem não é portanto senão disfarce, mentira e hipocrisia, tanto em si mesmo como para com os outros. Não quer que lhe digam a verdade. Evita dizê-la aos outros; e todas essas disposições, tão afastadas da justiça e da razão, têm uma raiz natural em seu coração").

16 Cf. Pascal, 2001, pp. 50-57, fragmentos LA 136-139.

17 Pascal diferencia entre a causa e a razão de nossa miséria. A causa é a agitação, a entrega ao divertimento, a impossibilidade de nos mantermos tranqüilos: "Quando às vezes me pus a considerar as diversas agitações dos homens, e os perigos, e as penas a que se expõem na Corte, na guerra de onde nascem tantas desavenças, paixões, ações ousadas e muitas vezes maldosas etc., repeti como frequência que toda a infelicidade dos homens provém de uma só coisa: de não saber ficar quieto num quarto" (Pascal, 2001, p. 50). A razão é a miséria de nossa condição, que só podemos conhecer plenamente através do mito da queda. Aconselhar ao homem que ele viva tranqüilo, como fazem alguns filósofos, é dizer-lhe que viva feliz, ou seja, é desconhecer sua condição: "Dizer a um homem que fique em repouso, é dizer-lhe que viva feliz. É aconselhar A. A. ter uma condição totalmente feliz e que possa considerar com calma, sem nela encontrar motivo de aflição (- Não é pois ouvir a natureza "LA 136, p. 52. Pascal retoma aqui um argumento que Montaigne utiliza no ensaio III, 9: "Da vanidade" ao acatar como relativamente justa a censura que se faz ao gosto pela viagem (a incapacidade de ficar quieto em um quarto): "Vejo a razão dessa advertência, e vejo-a muito bem; mas teria sido mais rápido e mais pertinente dizer-me em duas palavras: "sede sábio."” (Montaigne, 2001, III, 9, p. 304). O exame de si aconselha à dispersão, diz Montaigne, pois ele revela um eu repleto de inanidade e tolice: "Se os outros se examinassem atentamente, como faço, achar-se-iam como me acho, repletos de inanidade e de tolice. Delas não posso desfazer-me sem desfazer a mim mesmo. Estamos todos recheados delas, tanto uns como outros; mas os que o percebem levam uma certa vantagem, e ainda assim não sei”. (Idem, pp. 324-325). Montaigne aponta para um limite do conhecimento de si: "Era uma ordem paradoxal a que nos dava antigamente aquele deus em Delfos" (Idem, p. 325). Mas Pascal contesta que haja alguma vantagem neste conhecimento de si, mesmo que moderado. Sem o Deus cristão aquele que pretende conhecer esta condição é ainda 
b) o divertimento não nos torna felizes, mas contribui para aliviar a nossa miséria, na medida em que ele nos desvia momentaneamente de nós mesmos e entorpece a consciência que temos de nossa condição;

c) a paixão é uma condição necessária para que uma atividade possa funcionar como divertimento. Sem a presença de um elemento passional não nos entregamos verdadeiramente a uma atividade $^{18}$. Com este argumento Pascal se distancia da tese de Montaigne sobre a diversão. Em Montaigne a diversão é antes um método para combater as paixões imoderadas e tirânicas. Em Pascal o divertimento converte-se em uma teoria geral acerca da irracionalidade constitutiva das ações humanas, e não apenas dos afetos. A teoria do divertimento situa a ação humana no horizonte do desejo, cuja lógica consiste na reposição infinita de seus objetos. Pascal mantém o pressuposto eudaimonista da antropologia antiga, mas insiste na ausência de um horizonte último de sentido para as ações. Este horizonte só pode ser dado pela promessa da salvação. Os pressupostos teleológico

mais insensato do que aquele que a ignora e supõe encontrar sua felicidade no divertimento. A libido sciendi não é radicalmente distinta da libido dominandi e da libido sentiendi. São apenas modalidades distintas da mesma alienação do homem que se distanciou de Deus: "Da mesma forma que outros suam em seu gabinete para mostrar aos sábios que resolveram uma questão de álgebra cuja solução ainda não se tinha podido encontrar; e tantos outros se expõem aos maiores perigos para se vangloriar depois de uma praça que tomaram tão estupidamente, a meu ver. E finalmente outros se matam para aprender todas essas coisas, não para se tornarem mais sábios, mas tão-somente para mostrar que as sabem, e esses são os mais tolos do bando, pois que o são com conhecimento, ao passo que se pode pensar dos demais que não o seriam se tivessem esse conhecimento" (Pascal, 2001, p. 54). Esta última posição é a de Montaigne, o que o torna ainda mais censurável aos olhos de Pascal. Ele optou conscientemente pela diversão, quando dispunha de todas as condições para ver com clareza a necessidade da submissão. O reconhecimento da própria ignorância é ainda uma forma requintada do orgulho.

18 "Daí vem que o jogo e o entretenimento com mulheres, a guerra, os grandes empregos sejam tão procurados. Não é que neles haja realmente felicidade, nem que imaginemos que a verdadeira beatitude consista em se ter o dinheiro que se pode ganhar no jogo, ou na lebre que se persegue; nada disso nos interessaria se nos fosse oferecido de graça. Não é esse uso mole e sossegado e que nos deixa pensar em nossa infeliz condição que se busca, nem os perigos da guerra, nem o trabalho dos empregos, mas sim o ruído que nos desvia de pensar na nossa condição e nos diverte. Razão pela qual se gosta mais da caçada do que da presa” (Pascal, 2001, p. 51, com correções na tradução).

Cad. Nietzsche, Guarulhos/Porto Seguro, v.38, n.3, p. 125-180, setembro/dezembro, 2017. | 141 
Lopes, R.

e eudaimonista contidos na teoria grega da ação são assumidos e hiperinflacionados pela tradição cristã;

d) apenas o autoengano em relação ao valor da atividade ou do próprio agente permite transformar uma atividade rotineira em um engajamento passional, conferindo à forma de vida no interior da qual a atividade é realizada um peso que esta jamais teria se considerada de forma isenta pela razão. Pascal parece adotar o esquema clássico das três formas de vida: a dos prazeres, do poder e do conhecimento ${ }^{19}$. Toda paixão tem algo de afetação, na medida em que depende deste mecanismo de auto-persuasão ${ }^{20}$.

19 Cf. LA 545 (458). Pascal recorre à antropologia bíblica: "Tudo o que está no mundo é concupiscência da carne ou concupiscência dos olhos ou orgulho da vida. Libido sentiendi, libido sciendi, libido dominandi", e assume um esquema que desempenha um papel central em Agostinho, mas que corresponde em alguma medida à classificação aristotélica das três formas de vida: a vida dos sentidos, a vida política organizada em torno da luta pelo reconhecimento na esfera da polis, a vida contemplativa. Pascal, assim como toda a tradição cristã, contesta a dignidade intrínseca das formas de vida ditas superiores: a vida ativa e a vida contemplativa. Nietzsche destacou esta passagem em seu exemplar das obras de Pascal. Adiante veremos que o filósofo alemão se inspirou nesta passagem para repensar a vida contemplativa a partir de Aurora.

20 "Tal homem passa a vida sem tédio jogando todos os dias coisa de pouca monta. Dai-lhe todas as manhãs o dinheiro que ele pode ganhar a cada dia, sob a condição de ele não jogar, ireis tornálo infeliz. Dir-se-á talvez que o que ele busca é a brincadeira do jogo e não o ganho. Fazei então com que não jogue a dinheiro: ele não se animará e se aborrecerá. Não é então só a diversão que ele busca. Uma diversão desanimada e sem paixão o entediará. Ele precisa se animar e criar um engodo para si mesmo imaginando que seria feliz ganhando aquilo que não quereria que lhe fosse dado sob a condição de não jogar, a fim de que forme para si um motivo de paixão e que excite com isso o seu desejo, a sua cólera, o seu temor por esse objeto que formou para si como as crianças, que se apavoram diante do rosto que elas próprias lambuzaram de tinta" (Pascal, 2001, p. 54, com correções na tradução). $C f$. também a análise pascaliana do tema da glória, na qual são retomados alguns argumentos de Montaigne. Nada há de mais vão do que se esforçar pela glória, lutar pelo reconhecimento de seu próprio valor junto aos homens. Mas nada há ao mesmo tempo de mais elevado; e mesmo aqueles que fizeram o elogio de uma vida tranqüila, distante da agitação a que somos lançados quando nos dispomos a lutar pelo reconhecimento, não foram capazes de resistir ao charme desta paixão. No fragmento LA 470 Pascal retoma a linha geral do argumento de Montaigne, exposta no ensaio II, 16, intitulado "Da glória". Tanto Pascal quanto Montaigne tomam Epicuro como exemplo de que não é dado ao homem permanecer indiferente às seduções do renome. A razão nos mostra que a glória em si mesma é destituída de valor, mas ela é impotente para persuadir nossa natureza. E assim nos entregamos docemente ao logro. E é bom que o façamos, pois a luta pelo reconhecimento produz bons resultados para a sociedade. As crianças de Port-Royal caem na indolência por não receberem este estímulo ( $c f$. fragmento LA 63).

142 | Cad. Nietzsche, Guarulhos/Porto Seguro, v.38, n.3, p. 125-180, setembro/dezembro, 2017. 
Esta sequência de argumentos pode ser interpretada como uma tentativa de expor o custo ético e existencial do método terapêutico proposto por Montaigne. Pascal admite que o método da diversão e da dispersão tem uma eficácia relativa, mas esta eficácia exige o sacrifício do intelecto e uma indolente entrega ao autoengano e ao esquecimento de si no engajamento no mundo.

Mas não apenas a necessidade do divertimento é marca de nossa miséria. Nossa situação epistêmica não é uma testemunha menos eloquente desta condição. O fragmento LA 131 (434) é a fonte mais importante para a releitura pascaliana do ceticismo epistemológico. Pascal não considera que o ceticismo epistemológico esteja em contradição com a doutrina cristã. A ele interessa, entretanto, mostrar que a verdade do ceticismo epistemológico (a impossibilidade de apresentar fundamentos racionais para nossas convicções básicas) não conduz à suspensão do juízo, pois a razão é impotente para combater as demais fontes que atuam na formação e fixação de nossas crenças. O ponto de partida de Pascal é a versão radicalizada do ceticismo epistemológico elaborada por Descartes nas Meditações:

As principais forças dos pirrônicos, deixo de lado as menores, provêm de que não temos nenhuma certeza da verdade desses princípios, afora a fé e a revelação, senão (o fato de) que os sentimos naturalmente em nós. Ora, esse sentimento natural não é uma prova convincente de sua verdade, visto que, não tendo certeza afora a fé, se o homem foi criado por um deus bom, por um demônio mau ou ao acaso, ele fica em dúvida se esses princípios nos são dados ou como verdadeiros, ou como falsos, ou como incertos segundo a nossa origem (Pascal, 2001, p. 44) ${ }^{21}$

\footnotetext{
21 A principal força dos pirrônicos corresponde na verdade ao cenário epistêmico montado por Descartes com o auxílio da ficção de um deus enganador na primeira meditação: "Talvez haja, em verdade, aqueles que, a ter de crer que todas as outras coisas são incertas, prefiram negar um Deus tão poderoso. Não os contraditemos e admitamos que tudo o que dissemos sobre Deus seja fictício. Que suponham tenha eu chegado a ser o que sou pelo fado, pelo acaso, por uma série contínua das coisas ou por qualquer outro modo, pois que enganar-se e errar parecem ser uma certa imperfeição, quanto menos poderoso for o autor que designem à minha origem tanto mais provável será que eu seja tão imperfeito para que sempre erre" (Descartes, 2004, p. 21).
}

Cad. Nietzsche, Guarulhos/Porto Seguro, v.38, n.3, p. 125-180, setembro/dezembro, 2017. | 143 
Lopes, R.

Pascal recusa o recurso cartesiano à luz natural, seu apelo à evidência como marca de verdade, como ocorre, por exemplo, no caso do princípio de causalidade, e propõe uma interpretação naturalista de nossa adesão aos princípios. A razão, incapaz de fornecer uma justificação racional destes princípios, recomenda a cautela e a suspensão, mas a natureza é mais forte e nos obriga a crer à revelia desta recomendação. $O$ resultado é um conflito entre a razão cética, que depõe a favor dos pirrônicos e dos acadêmicos, e a natureza, que favorece os dogmáticos:

A natureza confunde os pirrônicos (e os acadêmicos) e a razão confunde os dogmáticos. Que vos tornareis então, ó homem que buscais qual é a vossa verdadeira condição por vossa razão natural? Não podeis fugir de uma dessas (três) seitas nem subsistir em nenhuma delas (Pascal, 2001, p. 47)

A impossibilidade de anular nossa crença nos primeiros princípios é utilizada por Pascal como uma evidência da incapacidade humana de preservar a integridade intelectual. A inclinação natural a crer está em contradição com o princípio ético da vida cética, segundo o qual só devemos dar nosso assentimento a proposições para as quais somos capazes de apresentar uma fundamentação racional ${ }^{22}$. O cético não pode negar assentimento aos princípios, embora eles sejam incertos em função do desconhecimento de nossa origem. Pascal está certo. Há uma contradição entre as exigências vitais e a versão cartesiana do ceticismo. Os cenários céticos esboçados por Descartes resultam de uma livre decisão da vontade de tomar como falso tudo aquilo que é meramente verossímil. Trata-se de um experimento de pensamento. Descartes propõe estes cenários com a intenção de testar a capacidade de nossas intuições epistêmicas de oferecer resistência a situações-limite. Na perspectiva de Descartes a dúvida metafísica e hiperbólica é uma ficção, proposta com o

22 Cf. Maia Neto, 1995.

144| Cad. Nietzsche, Guarulhos/Porto Seguro, v.38, n.3, p. 125-180, setembro/dezembro, 2017. 
intuito de extrair o verdadeiro através de uma exageração do falso. Pascal parece remeter a esta intenção cartesiana ao comentar o único ponto forte dos dogmáticos: "Detenho-me no único ponto forte dos dogmatistas, que consiste em que falando de boa-fé e sinceramente, não se pode duvidar dos princípios naturais" (Pascal, 2001, p. 45). A dúvida cética não é sincera. Embora Pascal remeta aos pirrônicos, esta acusação vale antes para a versão cartesiana do ceticismo em relação a princípios. O próprio Descartes chamou a atenção do leitor para esta insinceridade em um trecho fundamental da primeira meditação. $\mathrm{O}$ argumento cartesiano para justificar a dúvida metafísica apela para o princípio da prudência cognitiva, que nos ordena a não mais confiar naquilo que uma vez nos enganou. Trata-se de um artifício da vontade para combater a tendência natural da mente à credulidade e assim encontrar uma via segura para as ciências e recobrar a confiança em nossa faculdade de julgar:

Mas ainda não é suficiente que tenha notado essas coisas, devo cuidar de me lembrar delas, pois as opiniões costumeiras reaparecem ininterruptamente, a ocupar minha credulidade, a elas submetida quase contra minha vontade por um demorado trato e um direito de familiaridade.

Nunca vencerei o hábito de a elas assentir e nelas confiar, enquanto as supuser tais quais são deveras, a saber, de algum modo por certo duvidosas, como há pouco foi mostrado e, não obstante, muito prováveis, sendo muito mais consentâneo com a razão nelas acreditar do que negá-las.

Eis por que creio não esteja agindo mal, se, entrando voluntariamente numa direção de todo contrária, passe a me enganar a mim mesmo e finja por algum tempo que essas opiniões são de todo falsas ou imaginárias (Descartes, 2004, p. 22).

A formulação cartesiana do ceticismo epistemológico estabelece um abismo entre o nosso universo de crenças habituais e o exercício da dúvida hiperbólica, que se inscreve em um horizonte de excepcionalidade. Para aqueles que aceitam o cenário cartesiano da primeira meditação, mas recusam a solução que o filósofo francês 
Lopes, R.

apresenta na sequência deste escrito, passa automaticamente a valer a expressão lapidar cunhada por Hume para descrever a natureza de argumentos céticos: argumentos céticos são irrefutáveis, mas não persuasivos. Eles não interferem nos mecanismos de formação e fixação de nossas convicções básicas. Pascal dirá, retomando uma posição célebre de Aristóteles, que os princípios não podem ser demonstrados, mas tão somente intuídos. Esta certeza é indestrutível, mas não pode ser fundamentada racionalmente e, portanto, não oferece resistência a cenários de tipo cartesiano:

Conhecemos a verdade não apenas pela razão mas também pelo coração. É desta última maneira que conhecemos os primeiros princípios, e é em vão que o raciocínio, que não toma parte nisso, tenta combatê-los. Os pirrônicos, que só têm isso como objetivo, trabalham inutilmente nesse sentido. Nós sabemos que não estamos sonhando. Por maior que seja a impotência em que nos encontramos de prová-lo pela razão, essa impotência não permite concluir senão a fraqueza de nossa razão, mas de modo algum a incerteza de todos os nossos conhecimentos, como pretendem os pirrônicos [...] Os princípios se sentem, as proposições se concluem, e tudo com certeza, embora por diferentes caminhos - e é tão inútil e tão ridículo a razão pedir ao coração provas dos seus primeiros princípios por querer consentir neles, quando seria ridículo o coração pedir à razão um sentimento em todas as proposições que ela demonstra por querer recebê-las (LA 110 (282), citado a partir de Pascal, 2001, pp. 38-39, com correções na tradução).

A passagem acima não pode ser lida independente do fragmento LA 131 (434). A posição de Pascal diverge da aristotélica em um aspecto essencial: ele não reivindica uma intuição intelectual dos primeiros princípios. Nossa adesão a elas é fundada em um instinto natural. Mas esta confiança nos instintos é ameaçada pelo cenário cartesiano que nos lança na incerteza de nossa origem. Devemos confiar na natureza? E a força do hábito, outro fator igualmente decisivo na formação das crenças? Ele não poderia nos induzir em erro? O argumento prova apenas a impotência da razão discursiva. Mas isto não é nenhuma novidade, e o príncipe dos dogmáticos se

146 Cad. Nietzsche, Guarulhos/Porto Seguro, v.38, n.3, p. 125-180, setembro/dezembro, 2017. 
alinharia a Pascal e aos céticos neste ponto. Embora seja possível fornecer uma defesa indireta, dialética, dos primeiros princípios, ela jamais será uma prova apodítica de sua verdade. Estamos em um círculo. O que faremos? Pascal argumenta que nossa condição epistêmica espelha nossa condição moral: o ceticismo epistemológico é uma verdade apenas relativa, e esta relatividade se mostra na incapacidade da razão cética de persuadir a vontade a suspender seu assentimento aos primeiros princípios. $O$ voluntarismo doxástico de Descartes não corresponde à verdade da vida das crenças, sendo apenas uma simulação literária da razão discursiva. Os argumentos do ceticismo epistemológico não são persuasivos porque nós trazemos ainda alguma lembrança de nossa condição epistêmica originária. $O$ ceticismo epistemológico é resultado da queda. Em nossa condição epistêmica originária todas as verdades eram conhecidas pelo coração, pelo instinto ou intuitivamente. A razão discursiva é uma necessidade que se impõe aos homens em sua condição de seres decaídos:

Porque afinal, se o homem nunca tivesse sido corrompido, gozaria, em sua inocência, tanto da verdade como da felicidade com segurança. E, se o homem nunca tivesse sido senão corrompido, não teria nenhuma idéia da verdade, nem da beatitude. Mas desgraçados que somos, e mais do que se não houvesse grandeza em nossa condição, temos uma idéia da felicidade e não podemos chegar a ela. Sentimos uma imagem da verdade e não possuímos senão a mentira. Incapazes de ignorar de modo absoluto e de saber de modo certo, tão manifesto está que já estivemos num grau de perfeição do qual infelizmente decaímos (LA 131 Pascal, 2001, p. 47)

Esta passagem permite documentar com notável evidência o papel crucial que o pressuposto eudaimônico e teleológico desempenha na argumentação de Pascal. $\mathrm{O}$ fato de que não podemos deixar de nos orientar por uma idéia de verdade em nossa investigação, e por uma idéia de felicidade em nosso querer, é apontado por Pascal como a prova inequívoca de que somos reis depostos. A verdade e o bem são os fins da razão e da vontade. Fins inatingíveis, aos quais somos, entretanto, incapazes de renunciar. 
Lopes, R.

A incapacidade de renunciar à verdade como meta da investigação e ao bem como meta da vontade lança o homem em um estado de angústia e inquietação que só pode ser superado pela estratégia do divertimento. Esta insensibilidade e indiferença testemunham uma alienação sobrenatural. Para aqueles que aceitaram o desafio de Pascal de recusar o divertimento e permanecer no nível da razoabilidade resta apenas dar um passo adiante: o sacrifício da integridade intelectual, a submissão ao discurso da máquina. Sua porta de entrada é a aceitação do mito da queda, a horrível doutrina da transmissão do pecado.

\section{A resposta de Nietzsche ao desafio pascaliano}

Nietzsche mantém um estreito diálogo com a obra de Pascal no final de 1880 e início de 1881, conforme testemunham as diversas referências diretas ao jansenista nos póstumos do período e em Aurora $^{23}$. O filósofo se sente fascinado pela personalidade complexa de Pascal e é particularmente atraído pela intensidade de sua vivência religiosa. $\mathrm{O}$ interesse por sua obra, que é uma constante no pensamento de Nietzsche, atinge o seu ponto culminante nestes anos. Pascal é uma fonte de inspiração para todos aqueles que, apesar de reconhecerem claramente os limites do que pode ser demonstrado pela razão, recusam a suspensão do juízo e buscam, através de uma

23 Aurora é o livro de Nietzsche que reúne o maior número de menções diretas a Pascal: o jansenista é mencionado 9 vezes em um total de 23 menções no conjunto da obra. Nos póstumos existem 75 menções diretas a Pascal, sendo que 18 delas encontram-se nas notas póstumas que antecedem a publicação de Aurora (inverno de 1880-1881). O diálogo de Nietzsche com Pascal pode ser esquematicamente dividido em três momentos: nas obras de juventude Pascal é importante como epistemólogo e como moralista (Nietzsche assume uma posição similar à de Pascal e Hume em relação à natureza de nossa adesão aos princípios e transforma o conceito de divertimento em um instrumento de crítica da cultura moderna, em especial na primeira Extemporânea); no período intermediário Pascal fornece a Nietzsche elementos para sua reflexão sobre as condições de uma retomada da vida contemplativa que esteja à altura da espiritualidade cristã: ele é o adversário perfeito de uma nova forma de espírito livre, que não se confunde com o livre pensador moderno; na última fase Nietzsche enfatiza a proximidade entre Pascal e Schopenhauer e o elege como a vítima exemplar do cristianismo.

148 | Cad. Nietzsche, Guarulhos/Porto Seguro, v.38, n.3, p. 125-180, setembro/dezembro, 2017. 
concepção mais modesta da racionalidade, uma justificação para suas opções fundamentais. É sempre possível aprender com Pascal sem compartilhar suas opções fundamentais. Este aprendizado deve-se antes de tudo ao fato de que entre o ideal inatingível de uma razão puramente demonstrativa e a renúncia pura e simples à integridade intelectual o jansenista soube identificar graus intermediários de razoabilidade no âmbito das escolhas teóricas e práticas ${ }^{24}$. Nietzsche vê neste esforço incessante de identificar critérios alternativos de razoabilidade para as nossas escolhas o sintoma mais visível de uma vida interior caracterizada pelo inconformismo e pela paixão extrema pelas questões do espírito. Estes elementos exerceram um intenso fascínio sobre Nietzsche e o levaram a reconhecer em Pascal uma espécie de alma gêmea e de rival perfeito. Este fascínio ganha sua melhor expressão no aforismo 192 de Aurora, intitulado "Desejar para si adversários perfeitos":

Não se pode disputar aos franceses o fato de terem sido o povo mais cristão da Terra: não no sentido de que a crença religiosa das massas foi maior entre eles do que em outra parte qualquer, mas porque neles os mais difíceis ideais cristãos se transmutaram em seres humanos, não permanecendo apenas idéia, esboço, algo pela metade. Eis aí Pascal, o primeiro de todos

24 Entre a demonstração e a pura submissão há formas intermediárias de produzir um acordo entre as mentes. A Pascal interessa percorrer estas formas intermediárias para fazer seu leitor reconhecer a necessidade de transitar da adesão fundada na demonstração geométrica à submissão pura e simples à autoridade do guia espiritual. $\mathrm{O}$ argumento da aposta é um bom exemplo da notável habilidade de Pascal de operar no interior de formas moderadas de racionalidade. A Pascal interessa, sobretudo, mostrar que tanto a crença quanto a descrença, tanto o dogmatismo quanto o ceticismo, podem ser sintomas de fraqueza. Não apenas a credulidade, também a incredulidade pode denunciar a ausência de virtudes epistêmicas. Este argumento já está presente em Montaigne, no debate sobre os milagres. Pascal formulou esta tese de forma lapidar no fragmento LA 170: "Deve-se saber duvidar onde é preciso, ter certeza onde é preciso, submetendo-se onde é preciso. Quem não faz assim não houve a voz da razão. Existem pessoas que falham nesses três princípios: ou tendo certeza de tudo como demonstrativo, falta de conhecer-se em demonstração; ou duvidando de tudo, falta de saber onde é preciso se submeter; ou submetendo-se a tudo, falta de saber onde é preciso julgar. Pirrônico, geômetra, cristão: dúvida, certeza, submissão" (Pascal, 2001, p. 71). O texto onde Pascal discute os diversos mecanismos de formação da crença, assim como seus respectivos limites, é o opúsculo intitulado De l'esprit géometrique et de l'art de persuader (cf. Pascal, 1963, pp. 348-359). Neste opúsculo Pascal oferece uma defesa dialética da divisibilidade infinita do espaço que teve ampla repercussão em Nietzsche, conforme vimos no exame das preleções sobre os filósofos pré-platônicos. 
Lopes, R.

os cristãos na reunião de fervor, espírito e integridade intelectual - e considere-se o que teve de ser aqui reunido! (M/A, 192, KSA 3.165)

É também sob a influência deste fascínio que Nietzsche revê a imagem da vida contemplativa tal como esta havia se desenhado nas primeiras obras do período intermediário, sob a inspiração de Epicuro e Montaigne. O homem do conhecimento não deve se contentar em perseguir o ideal da moderação dos afetos através da suspensão do juízo moral. Ele deve agora buscar no conhecimento uma nova forma de intensificação do sentimento de poder. Para tanto não basta apenas dar continuidade ao projeto de banir os juízos morais, mas é necessário também propor novos juízos de valor, submetendo o conjunto dos afetos a uma nova avaliação e desenvolvendo mecanismos não ilusórios para a sua intensificação. Nietzsche permanece fiel ao intuito de reforma da vida afetiva: alguns sentimentos devem ser moderados, outros eliminados através da estratégia terapêutica derivada do método genealógico de abordagem das crenças. Mas a forma de vida filosófica em seu conjunto já não deve ser identificada com o cultivo da indiferença pirrônica. E isso significa, antes de tudo, a promoção de uma nova forma de afetividade. Há um conformismo moral no pirronismo que é incompatível com a retomada gradual da imagem heróica da vida filosófica no início dos anos 80. Nietzsche tem consciência disso e anuncia seu distanciamento desta posição no aforismo 477 de Aurora, intitulado "Redimido do ceticismo":

A: "Outros emergem de um ceticismo moral universal maldispostos e fracos, abatidos, corroídos por vermes, quase consumidos - eu, porém, mais corajoso e saudável do que nunca, de instintos reconquistados. Onde sopra um vento agudo, o mar se encrespa e não é pouco o perigo a superar, ali me sinto bem. Verme não me tornei, embora muitas vezes tivesse de trabalhar e escavar como um verme". - B: "Você deixou de ser cético! Pois você nega!" - A: "E com isso aprendi novamente a dizer Sim" (M/A 477, KSA 3.284"25).

25 Tradução de Paulo César de Souza (Doravante PCS), com uma pequena correção na tradução.

150 | Cad. Nietzsche, Guarulhos/Porto Seguro, v.38, n.3, p. 125-180, setembro/dezembro, 2017. 
Filosofia como forma de vida: o embate com o ceticismo moderno

Seria um erro concluir que Nietzsche se despede neste aforismo de toda e qualquer forma de ceticismo. Sua opção pelo ceticismo epistemológico é muito anterior ao seu compromisso com a promoção dos valores da ataraxia e da indiferença característicos da vida pirrônica e do epicurismo. Ao se distanciar destes valores a partir de Aurora, Nietzsche não altera suas posições céticas em epistemologia e nem é obrigado a fazê-lo por razões de consistência. A retomada de uma atitude construtiva no debate em torno dos valores, anunciada no aforismo 477, é de resto compatível com as demais motivações que Nietzsche associa à tradição cética. Nietzsche não é obrigado a rever seu compromisso com as virtudes epistêmicas associadas ao ceticismo metódico, nem tampouco com a integridade intelectual, embora nada o impeça de repensar a natureza e os limites deste compromisso, o que de fato ocorrerá, como veremos no final da presente exposição. $\mathrm{O}$ tipo de ceticismo do qual Nietzsche se redime neste aforismo deve ser identificado, portanto, com o ceticismo pirrônico em sua motivação terapêutica. Estar redimido do ceticismo pirrônico significa antes de tudo se despedir da agenda normativa mínima exposta no segundo volume de Humano, demasiado Humano, que pregava a reconciliação com as coisas próximas como a principal tarefa do filósofo. Nietzsche se distancia desta agenda em primeiro lugar por ceder aos argumentos de Pascal, que insistem na tensão entre o objetivo da ataraxia e a disposição de permanecer na investigação. Mas esta é apenas uma das razões, e talvez ela nem seja a principal. A segunda razão é que o filósofo se convence aos poucos de que uma reconciliação definitiva com as coisas próximas, caso ela seja possível, parece exigir um enfrentamento direto dos grandes temas da tradição metafísica. Esta segunda razão impõe a ele a necessidade de adotar uma nova agenda filosófica, na qual o filósofo procura se reconciliar com a especulação e se apresenta como alguém capaz de fazer frente aos desafios desta tradição ${ }^{26}$. Esta reconciliação, contudo, é acompanhada por tensões,

26 A partir do momento em que Nietzsche abandona a agenda normativa mínima que caracteriza sua adesão a Montaigne e Epicuro não há uma razão clara que o impeça de retomar seu compromisso

Cad. Nietzsche, Guarulhos/Porto Seguro, v.38, n.3, p. 125-180, setembro/dezembro, 2017. | 151 
Lopes, R.

recuos, tergiversações, dúvidas e, finalmente, por uma espécie de desistência ${ }^{27}$. Uma característica importante desta nova agenda filosófica é a retomada gradativa das pretensões políticas da vida contemplativa. Este processo de substituição da agenda filosófica é gradual, tendo seu ponto culminante em Além de Bem e Mal e Para a Genealogia da Moral. Mas não seria um exagero afirmar que este processo é deflagrado pela disposição de Nietzsche de rivalizar com o cristianismo de Pascal.

Em que consiste o desafio de Pascal aos olhos de Nietzsche? O desafio consiste em provar que o ateísmo pode ser um sinal de força, tanto do indivíduo quanto da cultura, e que pode haver uma forma heróica de ceticismo. Esta forma heróica de ceticismo permitiria conferir à opção pela vida filosófica um grau de intensidade e dramaticidade similar ao da opção pascaliana pela espiritualidade religiosa. $\mathrm{O}$ distanciamento dos valores terapêuticos relacionados ao ceticismo pirrônico e ao epicurismo é uma consequência natural deste projeto de vincular o ceticismo a sentimentos heróicos ${ }^{28}$. A questão

integral com o programa de Lange e atribuir uma nova legitimidade ao impulso especulativo, afora o fato de que este impulso esteve, na maior parte das vezes, a serviço da chamada ontologia moral. A questão é como se assegurar de que foi rompido o vínculo entre o interesse pelas questões últimas da metafísica e o espírito de vingança contra a vida, que segundo Nietzsche estaria na origem da moralização das categorias ontológicas. A possibilidade de uma interpretação da totalidade dos eventos como expressão de uma atitude afirmativa diante da vida é uma novidade que Nietzsche comunica aos seus leitores com alguma cautela a partir do Zaratustra. Que Nietzsche tenha adotado inicialmente a linguagem da poesia e da fábula para comunicar seus pensamentos reforça a tese de que a reconciliação com a especulação não significa a revisão de seu ceticismo em relação à possibilidade da metafísica como ciência. A opção pela linguagem poética permite ainda contornar as tensões que acompanharam a tentativa de execução do programa de Lange nas obras de juventude. Nietzsche jamais regride a uma concepção pré-crítica do problema da metafísica. Mas mesmo na qualidade de um experimento de pensamento, no final das contas Nietzsche não foi capaz de se decidir por uma interpretação da totalidade dos eventos a partir de uma extensão cosmológica da hipótese da vontade de poder. Esta indecisão por uma obra sistemática marca os últimos anos de produção de Nietzsche.

27 Conferir sobre isso Lopes, 2008, capítulo 3, seção 3.

28 Este projeto, que Nietzsche anuncia em um póstumo do inverno de 1883-1884, retoma um cenário, apresentado nos fragmentos póstumos de 1873, no qual o filósofo propõe um entrecruzamento possível entre ascese, heroísmo e ceticismo, em uma tentativa de releitura da ética schopenhaueriana. No início da década de 80 o adversário privilegiado passa a ser Pascal. Desta contraposição surge a

152 | Cad. Nietzsche, Guarulhos/Porto Seguro, v.38, n.3, p. 125-180, setembro/dezembro, 2017. 
é em que medida a cultura moderna comporta esta intensificação do sentimento de poder, já que ela não pode mais recorrer às ilusões que estavam na raiz da espiritualidade cristã. A via para o heroísmo encontra-se na promoção dos valores e virtudes relacionados ao moderno ethos científico, mas imprimindo a eles uma nova direção, distinta daquela assumida pelo projeto baconiano de domínio da natureza. $\mathrm{O}$ experimento nietzschiano de reconciliar conhecimento e vida contemplativa busca conferir um novo sentido ao cultivo das virtudes epistêmicas, de modo a fazer da ciência o espaço adequado para o exercício do controle de si e da autossuperação do homem moderno, convertendo a paixão pelo conhecimento no mais forte dos afetos.

Nietzsche procura associar a atividade filosófica em Aurora e Gaia Ciência a uma forma de paixão, a paixão pelo conhecimento ${ }^{29}$. Esta paixão estaria na raiz do compromisso do cético com a integridade intelectual [Redlichkeit]. O que confere especificidade à vida filosófica é menos um ethos do que um pathos, dirá Nietzsche. Em um fragmento póstumo de 1880, o filósofo enumera as etapas que o levaram a esta descoberta ${ }^{30}$. A paixão é um estado que não se impõe imediatamente, mas segue um itinerário com estações pré-fixadas, enumeradas por Stendhal em seu tratado sobre a paixão amorosa ${ }^{31}$. Stendhal é

distinção, formulada em Além de Bem e Mal, entre um ceticismo da força e um ceticismo da fraqueza (cf. os aforismos 208 e 209, KSA 5.137-140). O fragmento póstumo de 1883-1884 encontra-se em KSA, vol. X: p. 662: "Die Skepsis mit den heroischen Gefühlen verknüpfen. Skepsis der Schwäche und die des Muthes" (Nachlass/FP 24 [30], KSA 10.662).

29 Cf. Montinari, 1984; Brusotti, 1997; e Pippin, 2006. A leitura apresentada na sequência deve imensamente às sugestões de Marco Brusotti.

30 Trata-se de um plano para um livro em quatro capítulos, que teria como tema a história da integridade intelectual. Nietzsche pensou em diferentes títulos para o livro: "Zur Geschichte der Redlichkeit", "Die Leidenschaft der Redlichkeit"; "Passio nova, oder Von der Leidenschaft der Redlichkeit" ["História da integridade intelectual"; "A paixão da integridade intelectual"; "passio nova, ou Da Paixão da integridade Intelectual"] (Cf. Nachlass/FP 6 [461], 1880-81, KSA 9.316). O plano detalhado dos capítulos é apresentado no fragmento 7 [19] do mesmo período (fins de 1880). (Nachlass/FP 7 [19], 1880-81, KSA 9.320). A história da nova paixão é na verdade um relato autobiográfico do percurso de Nietzsche e das estratégias que ele utilizou para tentar escapar a esta paixão.

31 Cf. Stendhal, 1965, pp. 34-37. Stendhal enumera 7 etapas no processo que ele denomina de

Cad. Nietzsche, Guarulhos/Porto Seguro, v.38, n.3, p. 125-180, setembro/dezembro, 2017. | 153 
Lopes, R.

um interlocutor importante, pois ele permite a Nietzsche corrigir um aspecto central da teoria pascaliana das paixões pressuposta no argumento do divertimento: a tese segundo a qual a vida das paixões depende invariavelmente da vaidade e do logro aplicado a si mesmo ${ }^{32}$. Stendhal diferencia quatro modalidades de amor no

cristalização da paixão amorosa. Nada impede que o processo seja interrompido em uma das etapas, frustrando a experiência amorosa ou realizando-a apenas parcialmente.

32 Esta tese vale apenas para a teoria das paixões implícita no argumento do divertimento. Ela está ausente do pequeno ensaio intitulado Discours sur les passions de l'amour, cujo manuscrito foi descoberto por Victor Cousin em 1843. Cousin argumentou a favor de se atribuir a autoria deste manuscrito a Pascal em função das inúmeras expressões que nele se encontram e que são recorrentes nos Pensamentos. A teoria das paixões defendida neste ensaio antecipa algumas das teses que suportam a análise stendhaliana da paixão amorosa. Stendhal não cita Pascal e nem poderia ter tido acesso ao manuscrito. Mas a sua própria reflexão deve muito aos Ensaios de Montaigne, que é uma fonte comum aos dois textos. A edição das obras de Pascal utilizada por Nietzsche contém este ensaio. O exemplar de Nietzsche encontra-se preservado no acervo de Weimar (rubrica C304), e contém inúmeras marcações de leitura. Trata-se de um exemplar da tradução alemã feita a partir da edição francesa das obras de Pascal a cargo de P. Faugère, de 1844. Esta edição incorpora vários manuscritos até então inéditos, entre eles o manuscrito do Discours sur les passions de l'amour (na tradução alemã Über die Leidenschaft der Liebe. A versão alemã de 1865 acompanha a divisão em dois volumes da edição francesa de 1844. Cf. a referência bibliográfica completa em Pascal, 1865. A tese da autoria pascaliana defendida por Cousin foi questionada posteriormente. Nietzsche teve acesso a pelo menos dois autores que colocaram a autoria de Pascal em dúvida: Sainte-Beuve e F. Brunetière. Especialmente a leitura de Brunetière em 1887 parece ter tido um impacto decisivo sobre a imagem de Pascal presente nas últimas obras de Nietzsche. Brunetière assume a tese de Alexandre Vinet (1797-1847) de que o pessimismo traduziria melhor as posições essenciais de Pascal do que o pirronismo. As marcas de leitura deixadas por Nietzsche em seu exemplar do livro de Brunetière comprovam que ele acompanhou com grande interesse esta argumentação. Entre as inúmeras passagens sublinhadas por Nietzsche destaca-se o seguinte trecho, por sugerir uma nova perspectiva de interpretação para o conjunto da obra de Pascal: "Était-ce exagérer tout à l'heure que de dire qu'il ne serait pas sans fruit, après avoir tant parlé du "pyrrhonisme" de Pascal, d'examiner un peu son pessimisme? Et croyez-vouz que Vinet se trompât quand il y voulait voir la doctrine ou au moins l'une des bases de la doctrine des Pensées? Disons-le donc avec lui: le pyrrhonisme de Pascal n'est qu'une des formes ou une des faces de son pessimisme; et, de l'insuffisance de nous moyens de connaître, la conviction que tirent les Pensées n'est pas tant celle de notre impuissance à trouver la vérité que celle de notre corruption et de notre déchéance d'un état où nous peuvent seules remettre la religion et la vie chrétienne" [Estaríamos por acaso exagerando ao dizer que após tanta discussão sobre o "pirronismo" de Pascal seria útil conferir alguma atenção ao seu pessimismo? Teria Vinet se enganado ao querer ver no pessimismo a doutrina ou uma das bases da doutrina dos Pensées? Façamos coro a ele: o pirronismo de Pascal não é senão uma das formas ou facetas de seu pessimismo; a convicção que os Pensées extraem da insuficiência de nossos meios de conhecimento não é a de nossa impotência para encontrar a verdade, mas a de nossa corrupção e de nossa queda de uma condição à qual só podemos regressar mediante a religião e a vida cristã] (BRUNETIÈRE, 1887, p. 54; trechos sublinhados no exemplar de Nietzsche). De todo modo, a tese de que há uma 
primeiro capítulo de seu livro e concentra sua análise na forma mais nobre, a do amor-paixão. Dentro deste esquema, a tese de Pascal se aplica apenas às formas degradadas do sentimento amoroso (o amor fundado no prazer físico, ou na vaidade ou no refinamento do gosto $^{33}$. Stendhal atribui à imaginação o papel que Pascal pretende atribuir à vaidade e ao logro. A imaginação atua no processo de cristalização, fazendo com que o espírito apaixonado descubra em cada circunstância uma nova perfeição para o objeto de sua paixão. O processo de cristalização ocorre em duas etapas, sendo a segunda a decisiva, na medida em que ocorre após o momento de dúvida que se segue à primeira cristalização. $\mathrm{O}$ que garante duração à paixão amorosa é a segunda cristalização, pois ela sobreviveu à experiência da dúvida. A natureza e o ritmo das paixões em geral, não apenas das paixões amorosas, dependem diretamente das circunstâncias políticas e sociais, pois são estas circunstâncias que determinam o espaço de atuação da imaginação, sem a qual nenhuma cristalização é possível ${ }^{34}$. A paixão se alimenta das perfeições reais ou imaginárias

notável afinidade entre as visões de mundo de Pascal e Schopenhauer é defendida por Nietzsche muito antes de sua leitura de Brunetière. Por isso não devemos eliminar a hipótese de que Nietzsche tenha tido acesso direto ao livro de Vinet sobre Pascal. Vinet foi um teólogo protestante suíço de grande influência e um respeitável historiador da literatura francesa, que inspirou diretamente a geração de Sainte-Beuve. Ele lecionou na Basiléia e teve entre seus alunos o historiador e amigo pessoal de Nietzsche, J. Burckhardt. Nietzsche o cita uma única vez em uma nota póstuma de 1880, no mesmo período em que ele se ocupa intensamente de Pascal: "Es giebt eine komische Definition des Komischen: es soll, nach Vinet, die Naivetät der Sünde sein" (Nachlass/FP 3 [67], 1880-81, KSA 9.65). O livro de Vinet sobre Pascal: Études sur Blaise Pascal, foi publicado postumamente, "em 1848, e teve várias reedições até a segunda metade do século XX.

33 Cf. Stendhal, 1965, pp. 31-33.

34 Cf. Stendhal, 1965, capítulos LI a LIII, pp. 187-200. Elogio dos costumes e da regulamentação das práticas de cortejo e galanteio na civilização provençal. Origem moura desta civilização. Tudo isso é apresentado de forma hipotética e especulativa, inferido da produção poética e das anedotas que chegaram até nós e que são os únicos testemunhos desta esplendorosa cultura. O pressuposto é extraído de Montaigne: de que as paixões amorosas só podem florescer em um ambiente no qual as mulheres estejam em relação de igualdade com os homens nos jogos eróticos e existam dispositivos sociais para salvaguardar sua reputação. O intuito de Stendhal é fornecer uma ilustração histórica para a sua tese de que há uma íntima conexão entre as formas de governo e a vida das paixões. As relações de poder no interior da sociedade definem o ritmo, as formas e a intensidade das paixões. Dominada pelos jogos de salão e pela vaidade, a sociedade francesa, em contraste com a italiana, é

Cad. Nietzsche, Guarulhos/Porto Seguro, v.38, n.3, p. 125-180, setembro/dezembro, 2017. | 155 
Lopes, R.

de seu objeto, de sua inesgotável aptidão para nos causar prazer. Um regime que coíbe a imaginação, seja ele um regime político, seja um regime discursivo, como o da filosofia sistemática alemã, é um obstáculo ao desenvolvimento da grande paixão. $\mathrm{O}$ excesso de demonstração é um adversário temível da cristalização; ele expulsa a imaginação e impede a adesão amorosa. Não há promessa de felicidade onde todas as perfeições estão expostas. É necessário que a imaginação saia à caça de novas perfeições ${ }^{35}$.

Nietzsche retoma a classificação de Stendhal e a aplica às diversas motivações para o conhecimento no aforismo 123 de $A$ Gaia Ciência:

O conhecimento sendo mais que um meio. - Mesmo sem esta nova paixão - refiro-me à paixão do conhecimento -, a ciência seria fomentada: até agora a ciência cresceu e se desenvolveu sem ela. A boa fé na ciência, o preconceito a seu favor, que hoje predomina em nossos Estados (até na Igreja, antes), no fundo baseia-se no fato de que esse incondicional ímpeto

incapaz de oferecer as condições para o pleno desenvolvimento da grande paixão, independente de qual seja o seu objeto. Uma tese semelhante é defendida por Montaigne no ensaio III, 5, intitulado "Sobre versos de Virgílio". Montaigne defende a necessidade de uma reforma das práticas amorosas de sua época e das normas sociais que regem as relações matrimoniais como um pré-requisito para o cultivo nobre da paixão amorosa. Embora não discuta a necessidade de uma reforma das normas sociais que regem as relações amorosas, o pequeno ensaio atribuído a Pascal chama a atenção para o vínculo entre os costumes e as formas da paixão ( $c f$. Pascal, 1963, p. 285). O autor parece pressupor, entretanto, que o espírito forte é capaz de ultrapassar as restrições sociais que oprimem nossa sensibilidade: a grande paixão ("les passions de feu") é sua prerrogativa, pois somente ele está em condições de suspender o jugo das convenções e seguir seu coração, que lhe dita um ideal de beleza único ( $c f$. Idem, pp. 285-285). Nietzsche retoma esta tese no aforismo 39 de Gaia Ciência, ao reivindicar a primazia do gosto sobre as opiniões. Nietzsche defende que a mudança de opiniões é apenas um sintoma da mudança de gosto, e esta ocorre na medida em que um indivíduo expressa seu juízo de gosto e o impõe tiranicamente aos demais, que não são fortes o suficiente para lhe oferecer resistência. Um gosto singular supõe a coragem e a capacidade de ouvir sua própria sensibilidade e de afirmar as condições que intensificam o seu sentimento vital.

35 Cf. Stendhal, 1965, pp. 43-44. Para reforçar sua tese do papel da imaginação no processo de cristalização Stendhal recorre a exemplos tomados das mais diversas atividades: a constituição americana inibe a paixão política, o estilo de exposição da filosofia sistemática alemã impede que a reputação de seus pensadores dure mais que 40 anos, as crenças absurdas estimulam a paixão religiosa, a perspectiva do emprego futuro de uma determinada quantia estimula a paixão do jogo, a incapacidade de ter acesso aos seus próprios sentimentos conduz o mais sóbrio dos homens a uma adoração fanática da música.

156 | Cad. Nietzsche, Guarulhos/Porto Seguro, v.38, n.3, p. 125-180, setembro/dezembro, 2017. 
e pendor manifestou-se raramente nela, e de que justamente a ciência não é considerada uma paixão, mas um estado e um ethos. Com frequência basta o amour-plaisir do conhecimento (a curiosidade), basta o amour-vanité, habituar-se a ela com a segunda intenção de dinheiro e honrarias, e para muitos basta não saberem o que fazer com o ócio em demasia, exceto ler, colecionar, ordenar, observar, continuar relatando; o seu "impulso científico" é o seu tédio. [...] Na Antiguidade, a sua dignidade e seu reconhecimento eram diminuídos pelo fato de mesmo os seus mais fervorosos discípulos darem primazia à busca da virtude, e de que já se acreditava ter feito o mais alto elogio da ciência, ao festejá-la como o melhor meio para alcançar a virtude. Há algo novo na história, quando o conhecimento quer ser mais do que um meio (FW/GC 123, KSA 3.479, tradução de PCS).

O que está por trás de nosso interesse pelo conhecimento? Este é um problema que Nietzsche persegue desde a juventude. A tese de que a atividade teórica é desinteressada é um contra-senso. $\mathrm{O}$ interesse pelo conhecimento resulta de uma dinâmica interna dos próprios afetos. Mas como determinar a qualidade e intensidade destes afetos? Há uma paixão do conhecimento? Ou toda busca da verdade está subordinada a um cálculo instrumental? Estas perguntas visam a determinar o estatuto da vida contemplativa. Nas primeiras obras do período intermediário o compromisso de Nietzsche com a tese intelectualista fez com que a opção pela vida filosófica fosse identificada com o ideal da moderação das paixões. Esta opção se inscrevia em última instância no horizonte de um cálculo hedonista. Este ambiente teórico é caracterizado pela centralidade da distinção entre prazer e desprazer e pelo cálculo de utilidade. A tese intelectualista está intimamente associada à posição utilitarista em Nietzsche $^{36}$. Na versão nietzschiana desta tese, o agente, orientado

36 Diversos aforismos de Humano, demasiado Humano evidenciam esta identificação. Cf. o aforismo 102: "Sócrates e Platão estão certos: o que quer que o homem faça, ele sempre faz o bem, isto é: o que lhe parece bom (útil) segundo o grau de seu intelecto, segundo a eventual medida de sua racionalidade" (MA I/HH I 102, KSA 2.99, tradução de PCS). Esta identificação pode ter sido sugerida a Nietzsche pelo próprio John Stuart Mill. O filósofo inglês reivindica Sócrates como um ilustre predecessor da doutrina utilitarista na página de abertura de seu ensaio $O$ Utilitarismo: "Mais de dois mil anos se passaram e as mesmas discussões continuam, os filósofos são ainda agrupados 
Lopes, R.

pelo princípio de autoconservação, determina o seu querer em função de um cálculo de utilidade ${ }^{37}$. A divergência em relação à tradição utilitarista consiste na ênfase posta por Nietzsche no falibilismo do agente e na variabilidade do gosto. A constatação da infinita variabilidade do gosto encontra-se também em Montaigne e Pascal. Em Pascal, esta infinita variabilidade explica a impossibilidade de especificar regras exaustivas para a arte da persuasão, fato que ele identifica com um desregramento do entendimento e da vontade de origem sobrenatural $^{38}$. Em Nietzsche e em Montaigne esta constatação

sob as mesmas bandeiras rivais e nem os pensadores nem a humanidade em geral parecem mais próximos da unanimidade em relação à questão do que quando o jovem Sócrates escutava o velho Protágoras e sustentava [...] a teoria do utilitarismo contra a moralidade popular do assim chamado sofista" (Mill, 2000, p. 23). Nietzsche possuía uma tradução alemã das obras completas de Mill e seu exemplar deste ensaio contém inúmeros registros de leitura.

37 Cf. entre outros o aforismo 99 de Humano, demasiado Humano: "O que há de inocente nas chamadas más ações. - Todas as "más" ações são motivadas pelo impulso de conservação ou, mais exatamente, pelo propósito individual de buscar o prazer e evitar o desprazer; são, assim, motivadas, mas não são más. "Causar dor em si”" não existe, salvo no cérebro dos filósofos, e tampouco "causar prazer em si" (compaixão no sentido schopenhaueriano)" (MA I/HH I 99, KSA 2.95, tradução de PCS). É importante salientar que mesmo nesta fase Nietzsche não adere ao princípio normativo do utilitarismo, segundo o qual uma ação é boa apenas na medida em que ela permite produzir o máximo de prazer (felicidade) para as pessoas afetadas pela ação. Nietzsche acata apenas a tese psicológica subjacente ao princípio utilitarista, mas com o intuito de mostrar que a validade psicológica do princípio anula a distinção entre ações morais e imorais. Nietzsche não está, de modo algum, aceitando a tese de que "utilidade para o maior número" e "bondade moral" são expressões conceitualmente idênticas. Esta equação comprometeria o projeto de superação da interpretação moral do mundo. Outra divergência significativa em relação aos pressupostos utilitaristas é a tese de que o cálculo de utilidade realizado pelo agente se funda na crença, e não no conhecimento de que uma determinada ação permitirá a maximização do sentimento de prazer. $\mathrm{O}$ falibilismo das partes introduz um elemento importante nas relações de poder. Sem este elemento falibilista as relações de poder seriam uma expressão direta das relações de força objetivamente existentes, o que teria como resultado uma identificação entre força e direito. $\mathrm{O}$ direito expressa antes uma conformidade dos agentes a certas regras de justiça, que eles adotam em função do cálculo de poder realizado por cada um deles em um dado momento. Elas expressam, portanto, um equilíbrio provisório nas relações de poder, ao mesmo tempo em que contribuem para a manutenção deste equilíbrio. $C f$. o aforismo 93 de MA I/HH I: "O direito vai originalmente até onde um parece ao outro valioso, essencial, indispensável, invencível e assim por diante" (MA I/HH I 93, KSA 2.90). Neste aforismo as relações de poder são pensadas ainda a partir de um cálculo de utilidade, mas este cálculo está por sua vez submetido às leis da aparência. A concessão de direitos é o resultado de um equilíbrio entre os poderes; mas a atribuição de poder repousa na crença, e não no conhecimento efetivo da força de cada agente.

38 Cf. De l'art de persuader. Pascal reconhece no entendimento e na vontade as duas únicas potências responsáveis pela formação das crenças. $\mathrm{O}$ entendimento confere seu assentimento às verdades 
é apenas uma confirmação a mais do primado ontológico da diferença e da diversidade sobre a identidade e a permanência. A convergência do gosto é explicada pela impossibilidade, tanto para o indivíduo quanto para a sociedade, de assumir integralmente o ônus deste primado ontológico da singularidade ${ }^{39}$. Que o indivíduo escolha "contra" a sua natureza mais íntima (ou seja, sua falibilidade) é em parte o resultado dessa pressão social por coesão e coordenação. Uma relação estritamente pessoal com o mundo seria como retorna a um primitivo estado de natureza cognitivo, sem a mediação das

demonstradas e a vontade àquilo que lhe promete a felicidade. $O$ pleno domínio da arte de persuadir exigiria, portanto, um duplo domínio: o das regras da demonstração, que definem a arte de convencer, e o das regras do prazer, que definem a arte de agradar. Uma especificação exaustiva das regras da arte de agradar é impossível, pois no estado pós-lapsário a vontade humana é tão desregrada que não se submete a princípios firmes e estáveis de prazer. Ela é incapaz de se decidir pelos objetos cuja posse asseguraria a sua felicidade. Ela não apenas é incapaz de se deixar determinar pelas instruções do entendimento, como tende a interferir em sua esfera de competência.

390 aforismo 76 de A Gaia Ciência apresenta a tese de que é justamente a recusa, para a maior parte dos homens instintiva, de uma determinação puramente individual do gosto o que torna a vida humana em geral possível: "O perigo maior. - Não tivesse havido sempre um grande número de homens que vissem o disciplinar de sua mente - sua "racionalidade" - como seu orgulho, sua obrigação, sua virtude, que fossem ofendidos ou envergonhados por todas as fantasias e excessos do pensamento, enquanto amigos do "saudável bom senso", há muito a humanidade teria perecido! Sobre ela pairava e continua pairando, como o perigo maior, a irrupção da loucura - isto é, a irrupção do capricho no sentir, ver e ouvir, o gosto na indisciplina da mente, a alegria no "mau senso". O oposto do mundo dos loucos não é a verdade e a certeza, mas a universalidade e obrigatoriedade de uma crença, em suma, o que não é capricho no julgamento. E o maior trabalho dos homens até hoje foi entrar em acordo acerca de muitas coisas e submeter-se a uma lei da concordância - não importando se tais coisas são verdadeiras ou falsas. Esta é a disciplina da mente que conservou a humanidade" (FW/GC 76, KSA 3.431, tradução de PCS). A possibilidade da vida humana depende diretamente desta misteriosa capacidade de um acordo das mentes em torno de ficções comuns. Que a regra prevaleça sobre as exceções é um mistério para filósofos como Montaigne e Nietzsche, que apostam no primado ontológico da diferença e da diversidade. Os mecanismos naturais de formação de consenso são explicados por Nietzsche com a ajuda das modernas hipóteses biológicas. Mas uma indicação de Pascal também foi decisiva para que Nietzsche pudesse dimensionar a importância deste instinto de rebanho na esfera da cultura. A indicação encontra-se no fragmento LA 744: "Quando não se sabe a verdade de uma coisa, é bom que haja um erro comum que fixe o espírito dos homens". No exemplar de Nietzsche o trecho correspondente encontra-se destacado: Pascal, 1865, I, p. 241: "Wenn man die wahre Beschaffenheit einer Sache nicht kennt, so ist es gut, daß ein gemeinsamer Irrthum darüber vorhanden sei u. s. w. [quando não se sabe a verdadeira natureza de algo é bom que haja um erro compartilhado sobre isso etc...]"

Cad. Nietzsche, Guarulhos/Porto Seguro, v.38, n.3, p. 125-180, setembro/dezembro, 2017. $1 \mathbf{1 5 9}$ 
Lopes, R.

convenções sociais e seu imenso trabalho de categorização e filtragem da experiência.

Nietzsche rompe com a tese intelectualista ao negar ao prazer esta função motivadora e reduzi-lo a um mero fenômeno concomitante à atividade. $\mathrm{O}$ filósofo opera esta ruptura a partir de Aurora. $\mathrm{O}$ conceito de poder, que nas obras anteriores estava logicamente subordinado ao cálculo de prazer e ao princípio de autoconservação, ganha autonomia e é empregado na formulação de um princípio explicativo que tende a congregar em torno de si as demais hipóteses genealógicas. Este princípio é formulado como uma alternativa ao princípio de autoconservação e oferece, entre outras coisas, uma resposta aos paradoxos apontados por Pascal na teoria teleológica e eudaimonista da ação herdada da antropologia pagã e incorporada à tradição cristã ${ }^{40}$. Trata-se do princípio de intensificação e elevação do sentimento de poder. Nietzsche aplica este princípio aos mais variados fenômenos da cultura em Aurora. Uma de suas formulações encontra-se no aforismo 262 do referido livro:

O demônio do poder. - Não é a necessidade, nem a cobiça - não, o demônio dos homens é o poder. Seja lhes dado tudo, saúde, alimento, habitação, distração - eles continuam sendo infelizes e caprichosos: pois o demônio insiste em esperar, ele quer ser satisfeito. Seja-lhes tirado tudo, mas satisfaça-se a ele: então serão quase felizes - tão felizes quanto homens e demônios podem sê-lo (M/A 262, KSA 3.209, tradução de PCS)

Este princípio permite a Nietzsche oferecer uma explicação alternativa para a tese pascaliana da irracionalidade constitutiva das ações humanas; o caráter insaciável do desejo não expressa a nostalgia de uma plenitude vivenciada no estado anterior à queda. A tese segundo a qual nossas ações referem-se necessariamente a

40 Abel, 1998 (primeira edição 1984) foi o primeiro estudioso de Nietzsche a propor uma interpretação global de sua obra assumindo como princípio estruturador da leitura a oposição decidida do filósofo ao princípio de conservação.

$160 \mid$ Cad. Nietzsche, Guarulhos/Porto Seguro, v.38, n.3, p. 125-180, setembro/dezembro, 2017. 
um horizonte último de sentido traduz uma ilusão psicológica do agente. A felicidade não se encontra em um estado de repouso e plenitude, mas na intensificação do sentimento de poder que resulta da superação de obstáculos e nos engaja na busca incessante por novos desafios a serem superados, como forma de testar o próprio poder. Nietzsche parece responder tanto a Pascal quanto a Schopenhauer, cujas posições fundamentais ele tende progressivamente a identificar. A felicidade designa a intensidade de uma atividade, não a qualidade de um estado.

O princípio de intensificação do sentimento de poder permite a Nietzsche pensar uma ética heróica da autossuperação no horizonte da pura imanência, sem ter que recorrer a hipóteses teleológicas e eudaimonistas no sentido da teoria clássica da ação, herdada dos gregos e hiperinflacionada pela tradição cristã. Estes são os desafios teóricos enfrentados por Nietzsche em sua tentativa de esboçar uma forma de vida contemplativa capaz de rivalizar com o cristianismo de Pascal. A totalidade da vida espiritual é pensada no horizonte da libido dominandi. Nietzsche recusa a distinção pascaliana das três ordens (conforme a formulação do fragmento LA 308) e a substitui por uma concepção puramente gradual da fruição de si e do amor-próprio. No interior de uma mesma ordem ele pensa a espiritualidade religiosa, a paixão do conhecimento e as diversas expressões do pathos do mando e de obediência. A recusa de uma distinção ontológica entre as diferentes formas de vida não deve impedir uma hierarquização, que remete a diferenças puramente gradativas e de intensidade na fruição do poder. Estes experimentos do início da década de 80, circunscritos ao âmbito da psicologia do sentimento de poder, preparam o terreno para experimentos mais ousados no âmbito da ontologia, com a introdução da hipótese da vontade de poder. Esta hipótese, que propõe uma extensão cosmológica dos resultados obtidos no campo dos fenômenos antropológicos, é anunciada pela primeira vez no Zaratustra como um substituto para a concepção 
Lopes, R.

schopenhaueriana da vontade de viver e desenvolvida com algum detalhe apenas nos póstumos da segunda metade da década de 80 . Em sua disputa agonística com Pascal, Nietzsche principia por situar a espiritualidade religiosa no mesmo patamar da espiritualidade filosófica e da luta pelo reconhecimento na esfera política: na vida das paixões e em seus mecanismos secretos de fruição do próprio poder $^{41}$. Nesta confrontação com Pascal as tarefas são, entretanto, distintas. A primeira tarefa consiste em argumentar que a religiosidade de Pascal corresponde à experiência espiritual da paixão; a segunda tarefa consiste em estabelecer as condições sob as quais uma nova forma de vida contemplativa poderia rivalizar em intensidade com a paixão religiosa vivenciada por Pascal no interior do cristianismo; em outros termos, trata-se de pensar sob quais condições a busca do conhecimento poderia se converter em uma grande paixão e rivalizar com estados de elevação e tensionamento da alma produzidos por meio de mecanismos ilusórios.

A possibilidade de descrever o fervor religioso de Pascal em termos de engajamento erótico foi sugerida a Nietzsche pelo opúsculo Discours sur les passions de l'amour, até então atribuído ao jansenista, e pelo pequeno ensaio intitulado Sur la conversion du pécheur. Pascal descreve as vivências interiores do recém-convertido em termos muito similares aos empregados pelo autor do opúsculo para descrever os efeitos da paixão amorosa sobre a alma ${ }^{42}$. Nietzsche reproduz um

41 Com este movimento Nietzsche anula a distinção pascaliana das três ordens (a da carne, a do espírito e a da caridade ( $c f$. fragmento LA (308)), sem abandonar com isso a metáfora de um movimento de ascensão cara à tradição filosófica desde Platão.

42 Cf. Pascal, 1963; para a descrição dos efeitos da paixão amorosa $c f$. p. 288; para os efeitos da conversão pp. 290-291. A alma apaixonada não encontra contentamento em nenhum outro objeto senão no objeto da paixão; ela jamais esgota as perfeições deste objeto; a comparação com outros objetos tende a anular o valor destes; a grande paixão exige exclusividade; ela crê na sua própria eternidade; ela eleva a alma e a torna magnânima; o homem apaixonado esquece todos os seus demais compromissos, as amizades, os parentes, a fortuna, pois ele encontra sua plenitude no deleite da própria paixão. Todos estes efeitos têm seu correlato na alma do pecador recém-convertido. Todos os excessos característicos da grande paixão estão presentes na entrega incondicional a Deus. Apenas nele pode a alma encontrar seu contentamento; ela visa a uma felicidade que é eterna e reduz todos os anteriores objetos de afeição a nada.

162 | Cad. Nietzsche, Guarulhos/Porto Seguro, v.38, n.3, p. 125-180, setembro/dezembro, 2017. 
trecho do opúsculo em uma nota póstuma de 1878. Na passagem o autor sugere que a intensidade e pureza de uma paixão dependem diretamente da pureza e força do espírito, o que contradiz o intuito de difamar as paixões presente nos Pensamentos. A tese de que as paixões comportam graus distintos de nobreza em função da nobreza do espírito que lhes dá acolhimento está em particular contradição com a teoria das paixões pressuposta no argumento do divertimento ${ }^{43}$. Nos póstumos de 1880, Nietzsche associa explicitamente a religiosidade pascaliana a uma modalidade de engajamento erótico:

O estado de Pascal é uma paixão, que tem todos os sintomas e efeitos de felicidade, miséria e a mais profunda e duradoura seriedade. Por isso é particularmente risível vê-lo tão orgulhoso frente às paixões - é uma espécie de amor que a todos os outros despreza e se compadece dos homens que dele carecem (Nachlass/FP 7 [233], 1880, KSA 9.366)

Este engajamento erótico gera na alma uma tensão interna que cria as condições optimais para o exercício da autossuperação. A distância que se estabelece entre a imagem daquilo que se venera e a imagem daquilo que se é tem um efeito disciplinador sobre a alma. Obter este efeito sem recorrer a meios ilusórios é justamente o que caracteriza a ambição de Nietzsche neste momento ${ }^{44}$. A intensidade

$43 C f$. a passagem no original francês em Pascal, 1963, p. 285, que Nietzsche cita em sua tradução alemão em uma nota póstuma (cf. Nachlass/FP 36 [3], 1878-79, KSA 8.572): “La netteté de l'esprit cause aussi la netteté de la passion: c'est pourquoi un esprit grand et net aime avec ardeur, et il voit distinctement ce qu'il aime.." Esta passagem contraria frontalmente o que é dito sobre as paixões no argumento do divertimento: que as paixões têm como pressuposto a vaidade, o auto-engano e a dissimulação da verdadeira natureza do objeto. Este pressuposto não é válido para as paixões cultivadas pelos espíritos fortes, que vêem claramente aquilo que eles amam. $\mathrm{O}$ conhecimento do objeto não ofusca o ardor da paixão nobre.

$44 \mathrm{O}$ fascínio de Nietzsche pelo tipo de espiritualidade que ele associa a Pascal é um dos fatores que o afasta das demais versões do ateísmo da segunda metade do século XIX. Nietzsche admira o ateísmo resoluto de Schopenhauer, mas não pode perdoar a ele o fato de não ter se libertado da visão moral de mundo (Nachlass/FP 7 [68], 1885-87, KSA 12.321). O ateísmo de Schopenhauer segue sendo, entretanto, mais conseqüente do que a versão rósea do ateísmo humanista associada ao hegelianismo de esquerda, pois ele não se deixou contaminar pelo otimismo humanista do século XVIII. Contra o ateísmo humanista Nietzsche faria coro com Pascal: "Athéisme marque de force

Cad. Nietzsche, Guarulhos/Porto Seguro, v.38, n.3, p. 125-180, setembro/dezembro, 2017. | 163 
Lopes, R.

deste engajamento erótico permite à alma expandir indefinidamente seus espaços interiores. É possível propor experimentos de tal magnitude fora do ambiente do ideal ascético? O homem do conhecimento é capaz de cultivar esta atitude de reverência por si mesmo e por seu objeto? Nossa interação cognitiva com o mundo é capaz de criar por si só esse pathos da distância que Nietzsche identifica como a condição de possibilidade para o engajamento do indivíduo nesse exercício contínuo de autossuperação? Em um primeiro momento Nietzsche vê no compromisso com a integridade intelectual e na combinação de ceticismo epistemológico com disposição investigativa as condições optimais para o desenvolvimento de uma forma de vida caracterizada pela paixão do conhecimento. Mas já por ocasião da publicação de A Gaia Ciência Nietzsche procura nuançar esta posição e propõe a arte como um contrapeso aos excessos da consciência intelectual. Em Aurora Nietzsche descreve sua oposição ao cristianismo de Pascal como a oposição entre duas estratégias distintas para a fruição do poder, expressas na capacidade do sujeito de se impor uma disciplina que o conduz à superação de si. No fragmento intitulado "Comparação com Pascal", Nietzsche promove um rápido balanço das duas posições:

Comparação com Pascal: não temos nós também nossa força na autodisciplina, como ele? Ele em benefício de Deus, nós em benefício da integridade intelectual? De fato: um ideal que arranca os homens de si mesmos e do mundo cria as mais inusitadas tensões, é um contínuo contradizer-se a si mesmo no mais profundo, um venturoso repousar acima de si, no desprezo

d'esprit, mais jusqu'à un certain degré seulement” (Pascal, 1963, p. 522; LA 157 (225)). O desafio que se coloca para Nietzsche é justamente este: como fazer do ateísmo a fonte de novas energias espirituais? Os contemporâneos de Nietzsche são ateus segundo as mesmas leis da inércia espiritual que fizeram dos contemporâneos de Pascal cristãos sinceros. Como tornar o ateísmo uma opção radical, e não apenas uma mera conformidade à moda? $\mathrm{O}$ ateísmo deve ser vivido com a mesma paixão com que Pascal se entregou a seu cristianismo jansenista. Mas é possível um engajamento erótico no ateísmo? Sim, tão logo seja possível vislumbrar os compromissos extremos implicados por um ateísmo consequente. Tais compromissos se deixam traduzir na tarefa de superação da visão moral de mundo. A adesão a esta tarefa seria capaz de tensionar novamente $o$ arco da vida interior e produzir uma nova forma de vida contemplativa.

164 Cad. Nietzsche, Guarulhos/Porto Seguro, v.38, n.3, p. 125-180, setembro/dezembro, 2017. 
por tudo aquilo que se chama "eu". Nós somos menos amargos e também menos repletos de vingança contra o mundo, nossa força é menor, não há dúvida, por isso não nos consumimos tão rápido, feito brasas, mas temos a força da duração (Nachlass/FP 7 [262], 1880-81, KSA 9.372).

A perda de intensidade da vida espiritual acarretada pelo declínio do ideal cristão deve ser compensada por uma nova disciplina, imposta pela integridade intelectual. Esta se manifesta por sua vez na renúncia a toda forma de certeza última, a todo anseio por garantias definitivas. $\mathrm{O}$ anseio por tais garantias é sintoma de um declínio das paixões individuais, que foram aviltadas e vinculadas à má consciência $^{45}$. A integridade intelectual não deve ser interpretada como um imperativo moral da vida intelectual. Nietzsche a apresenta ora como expressão de um juízo de gosto, ora como a mais nova das virtudes. A disposição cética, associada ao compromisso com a integridade intelectual, com a atitude investigativa e com a desconfiança instintiva face à tradição, é igualmente identificada com o estado amoroso:

A disposição cética tem seu paralelo: "antes morrer faminto do que comer algo repugnante". As opiniões das autoridades se tornaram repugnantes a nós - antes morrer de fome! Isto é uma paixão rara! A disposição cética é uma paixão (Nachlass/FP 6 [122], 1880-81, KSA 9.226).

45 Uma conjunção de fatores teria feito do mundo moderno um ambiente hostil ao desenvolvimento das grandes paixões, que são sempre paixões individuais: "Wodurch ist das Bedürfniß nach einem festen Halt so groß geworden? Weil wir angelehrt worden sind, uns zu mißtrauen: $\mathrm{d}$. h. weil wir keine Leidenschaft mehr haben dürfen, ohne schlechtes Gewissen! Durch diese Verlästerung unseres Wesens ist der Trieb nach Gewißheit außer uns so groß geworden: 1) religiöser Weg 2) wissenschaftlicher Weg 3) Hingebung an Geld Fürsten Parteien christliche Sekten usw.: welche wir fanatisch nehmen müssen, also falsch verstehen müssen, damit sie uns das Begehrte leisten [O que fez com que a necessidade de algo firme se tornasse tão grande? Porque fomos ensinados a desconfiar de nós mesmos: d. h. porque não podemos mais ter paixão sem má consciência! Foi graças à difamação de nosso ser que o impulso por certeza por algo fora de nós se tornou tão grande: 1) maneira religiosa 2) maneira científica 3) devoção ao dinheiro, príncipe, partidos, seitas cristãs etc.: aos quais precisamos aderir de forma fanática, isto é, interpretar de forma equivocada, de modo que eles possam conduzir nosso desejo] " (Nachlass/FP 7 [256], 1880-81, KSA 9.370).

Cad. Nietzsche, Guarulhos/Porto Seguro, v.38, n.3, p. 125-180, setembro/dezembro, 2017. | 165 
Lopes, R.

Ao associar a busca do conhecimento a uma paixão, Nietzsche rompe provisoriamente com sua tendência a derivar o interesse pela verdade de um compromisso com pressupostos morais. $\mathrm{O}$ interesse pela verdade, que o jovem Nietzsche havia associado à internalização e moralização das regras sociais da veracidade (tese desenvolvida no opúsculo intitulado Sobre Verdade e Mentira no Sentido Extramoral), pode ser apresentado agora como o resultado de um engajamento erótico. Nietzsche confere à paixão pelo conhecimento todos os traços que Stendhal associa à grande paixão: a disposição para o sacrifício, a recusa do comportamento pragmaticamente orientado, a crença na própria eternidade, a tendência a conferir ao objeto da paixão todas as perfeições, a infelicidade característica dos amantes, que nunca podem estar seguros de uma posse definitiva do objeto de seu afeto, a entrega que não é uma alienação, mas uma intensificação do sentimento vital, a afirmação de sua singularidade através da expressão do gosto, a promessa de felicidade. No aforismo 429, intitulado "A nova paixão", Nietzsche formula um experimento de pensamento no qual ele atribui à paixão do conhecimento as principais características destacadas por Stendhal em seu exame da paixão amorosa. O cristianismo de Pascal segue servindo de contraste para a nova paixão:

Por que tememos e odiamos um possível retorno à barbárie? Porque ela tornaria os homens mais infelizes do que são? Ah, não! Em todos os tempos os bárbaros tiveram mais felicidade, não nos enganemos! - Mas nosso impulso ao conhecimento é demasiado forte para que ainda possamos estimar a felicidade sem conhecimento ou a felicidade de uma forte e firme ilusão; apenas imaginar esses estados é doloroso para nós! A inquietude de descobrir e solucionar tornou-se tão atraente e imprescindível para nós como o amor infeliz para aquele que ama: o qual ele não trocaria jamais pelo estado de indiferença; - sim, talvez nós também sejamos amantes infelizes! O conhecimento, em nós, transformou-se em paixão que não vacila ante nenhum sacrifício e nada teme, no fundo, senão a sua própria extinção; nós acreditamos honestamente que, sob o ímpeto e o sofrimento dessa paixão, toda a humanidade tenha de acreditar-se mais sublime e consolada do que

166 | Cad. Nietzsche, Guarulhos/Porto Seguro, v.38, n.3, p. 125-180, setembro/dezembro, 2017. 
antes, quando ainda não havia superado a inveja do bem-estar grosseiro que acompanha a barbárie. E talvez até que a humanidade pereça devido a essa paixão do conhecimento! - mas nem este pensamento influi sobre nós! O cristianismo se atemorizou alguma vez ante um pensamento assim? Não são irmãos o amor e a morte? Sim, odiamos a barbárie - preferimos todos o fim da humanidade ao retrocesso do conhecimento! E, afinal: se a humanidade não perecer de uma paixão, perecerá de uma fraqueza: o que é preferível? Eis a questão principal. Queremos para ela um final em luz ou em areia? - (M/A 429, KSA 3.264, tradução de PCS)

Todas estas características opõem o engajamento erótico ao engajamento moral. Através da paixão nobre o indivíduo se entrega a algo fora de si mesmo, mas através desta entrega ele afirma simultaneamente a sua própria singularidade, pois sua paixão o distingue na medida em que elege um objeto que se caracteriza pela raridade e que não desperta na maioria dos homens senão indiferença. A submissão a um imperativo moral, por sua vez, tem um efeito oposto: o indivíduo aliena sua própria vontade em nome de um partido, de um príncipe, de uma igreja, de um preceito. Através deste movimento de alienação da própria vontade o indivíduo transfere sua responsabilidade, recusa a tarefa do mando e se submete. Esta submissão pode ser uma fonte inesgotável de força, pois ela evita a dispersão da vontade. Esta é, portanto, uma estratégia oblíqua para a fruição do poder. A grande paixão, por sua vez, recusa o cálculo utilitário e o princípio da autoconservação como sinais de uma prudência excessivamente egoísta e vulgar. Nietzsche estabelece este contraste entre as naturezas nobres e vulgares nos primeiros aforismos de A Gaia Ciência. A força derivada da submissão a um dever incondicional é contrastada com a força derivada da paixão. A primeira exige a anulação de toda escala pessoal de valores como forma de ocultar a própria fraqueza ou transmutá-la em força: o valor não é referido ao próprio querer, mas a uma autoridade qualquer, que pode ser a autoridade de uma pessoa, de uma instituição ou ainda de um preceito moral metafisicamente fundado. $\mathrm{O}$ importante é que a 
Lopes, R.

responsabilidade pelos valores seja transferida para outra instância que não a da própria vontade, e que esta instância esteja em condições de exigir para si uma adesão incondicional. Justamente por isso os indivíduos que pregam este tipo de submissão são os opositores naturais do ceticismo e do esclarecimento moral ${ }^{46}$. $\mathrm{O}$ espírito forte, por sua vez, é aquele cuja força se expressa na afirmação de sua própria vontade, sem recorrer à ilusão de um fundamento último para o seu querer. Sua paixão é rara e demonstra a idiossincrasia de um gosto excessivamente singular. Entregue à sua paixão, o espírito nobre é incapaz de compreender que o restante da humanidade não esteja sujeito às mesmas leis que movem sua vida interior. Esta é sua forma de parcialidade, sua eterna injustiça. O espírito forte é uma exceção e não consegue se perceber como tal. $\mathrm{O}$ homem tomado pela paixão do conhecimento também age deste modo pouco razoável. É esta falta de razoabilidade característica do estado amoroso que leva o homem do conhecimento, no auge de sua paixão, à crença de que seu compromisso com a consciência intelectual é um compromisso que deveria valer para o ser humano enquanto tal. Ele interpreta seu pathos interior como um ethos e espera encontrar em todos os homens esta mesma disposição para com a verdade. A Gaia Ciência é a obra na qual Nietzsche, motivado por estas reflexões, revê a natureza de seu compromisso com a consciência intelectual. Isto ocorre já no segundo aforismo, que tem como título "A consciência intelectual":

Continuo tendo a mesma experiência e me rebelando igualmente sem cessar contra ela, não desejo acreditar nela, ainda que me seja palpável: a grande maioria das pessoas não tem consciência intelectual; e frequentemente quis

46 "Por quererem que se tenha absoluta confiança neles, necessitam antes confiar absolutamente em si mesmos, com base em algum derradeiro e indiscutível mandamento, inerentemente sublime, do qual gostariam de sentir-se e aparecer como servidores e instrumentos. Temos aqui os opositores mais naturais, em geral muito influentes, do esclarecimento moral e do ceticismo [...] Toda servilidade mais sutil se apega ao imperativo categórico e é inimiga mortal daqueles que querem tirar ao dever seu caráter incondicional: é o que exige deles a decência, e não apenas a decência" (FW/GC 5, KSA 3.377/78 tradução de PCS).

168 | Cad. Nietzsche, Guarulhos/Porto Seguro, v.38, n.3, p. 125-180, setembro/dezembro, 2017. 
me parecer que se alguém a exige, nas mais populosas cidades, acha-se tão só como no deserto. Cada qual olha para você com olhar estrangeiro e prossegue no uso da sua balança, chamando a isso de bom e àquilo de mau; ninguém se enrubesce, quando você dá a entender que os pesos não estão justos - tampouco há indignação contra você: talvez riam de sua dúvida. Quero dizer: a grande maioria não acha desprezível acreditar isso ou aquilo e viver conforme tal crença, sem antes haver se tornado consciente das últimas e mais seguras razões a favor ou contra ela, e sem mesmo se preocupar depois com tais razões - os mais talentosos homens e as mais nobres mulheres também fazem parte dessa grande maioria. Mas que significam bondade, finura e gênio para mim, quando a pessoa que tem essas virtudes tolera em si mesma sentimentos frouxos ao crer e julgar, quando a exigência de certeza não constitui para ela o mais íntimo desejo e a mais profunda necessidade - o que distingue os homens superiores dos inferiores! Em algumas pessoas piedosas encontrei ódio à razão e isso me agradou nelas; ao menos se revelava assim a má consciência intelectual! Mas estar em meio a essa rerum concordia discors e toda a maravilhosa incerteza e ambiguidade da existência e não interrogar, não tremer de ânsia e gosto da interrogação, nem sequer odiar quem interroga, talvez até se divertindo levemente com este - isto é o que percebo como desprezível, e tal percepção é o que busco primeiramente em cada indivíduo: - algum desatino está sempre a me convencer de que todo ser humano tem esta percepção, como ser humano. É minha espécie de injustiça (FW/GC 2, KSA 3.373 tradução de PCS).

A consciência intelectual parece exigir do agente cognitivo o mesmo que a consciência moral kantiana exige do agente moral: que ele obedeça incondicionalmente a preceitos epistêmicos que devem valer universalmente. Pois somente deste modo seria possível promover os valores e as virtudes epistêmicas sem os quais os seres humanos se tornam desprezíveis. Kant afirma que todos os bens da fortuna, os talentos intelectuais e as virtudes relacionadas ao temperamento não têm valor algum, exceto aquele derivado do uso que uma vontade boa lhes confere. Este argumento, enunciado no primeiro parágrafo da Seção I da Fundamentação da Metafísica dos Costumes, antecipa a tese nuclear da teoria kantiana dos valores: 
Lopes, R.

apenas a boa vontade tem um valor absoluto; tudo o mais tem valor puramente instrumental. Aos olhos de Nietzsche, essa reivindicação equivale à tirania dos valores morais sobre os demais valores, à qual a filosofia de Kant confere acabada expressão conceitual. A tentativa de interpretar o compromisso com a consciência intelectual como o resultado de um engajamento erótico tem como objetivo evitar que o filósofo se torne um defensor fanático de seu estilo de vida e acabe ele mesmo tiranizado pelos valores lógicos. Mas esta tentativa é parcialmente frustrada e Nietzsche se vê obrigado a recorrer à arte como forma de frear esta ameaça constante de uma recaída nos excessos da moralidade.

As tensões que atravessavam o programa filosófico do jovem Nietzsche foram geradas em parte por uma interpretação rigorista das exigências da consciência intelectual. A adesão simultânea de Nietzsche à tese da inevitabilidade antropológica da metafísica e ao ceticismo epistemológico, que estava na raiz de sua tentativa de conferir um sentido metafísico à atividade estética, excluía de antemão a possibilidade de cumprir minimamente os requisitos da consciência intelectual em sua interpretação rigorista ${ }^{47}$. Nietzsche redigiu o aforismo 2 de A Gaia Ciência dez anos após a publicação de seu primeiro livro. Algumas declarações do jovem Nietzsche permitiriam identificá-lo com a posição misológica que neste aforismo ele atribui a alguns homens piedosos. $\mathrm{O}$ ódio declarado à razão é ainda uma atitude honesta, mais honesta do que a atitude de indiferença frente às exigências da consciência intelectual. Esta é enfim a posição de Pascal, e esta é uma das razões pela qual Nietzsche o estima: ele é intelectualmente honesto em seu sacrifício do intelecto. Mas ele não estaria no final das contas certo? Em que medida é possível cumprir as exigências da consciência intelectual? Nietzsche reconhece que suas exigências não podem ser: 1) universalmente válidas, pois elas se impõem a alguns poucos indivíduos de exceção, que são

47 Cf. sobre isso Lopes (2008, capítulo I, seção 3).

$170 \mid$ Cad. Nietzsche, Guarulhos/Porto Seguro, v.38, n.3, p. 125-180, setembro/dezembro, 2017. 
dominados por uma espécie de apetite investigativo (libido sciendi), e que é em última instância uma das manifestações da vontade de poder (libido dominandi); 2) nem incondicionalmente cumpridas, pois elas eliminariam a possibilidade mesma do conhecimento. O conhecimento mesmo é uma forma de erro; se a consciência intelectual, cegamente obedecida, não tolera nenhuma forma de ilusão ou pressuposto não fundamentado, então as bases sobre as quais a ciência está edificada desabam. $\mathrm{O}$ conhecimento como uma forma de vida, como um aliado da vida e da intensificação do sentimento de poder deixa de existir. Neste cenário os argumentos de Pascal contra a integridade intelectual se mostram válidos em alguma medida, pois o próprio conhecimento se funda no erro e na aceitação consciente da ilusão. Podemos reagir a isso recorrendo a mecanismos ilusórios que nos prometem uma reconciliação futura, ou podemos assumir o que há de tolo e parcial em nossa paixão pelo conhecimento. Nessa medida, Montaigne volta a ser um aliado fundamental no projeto de uma gaia ciência. $\mathrm{O}$ que há de paradoxal nessa tarefa é a exigência de que sejamos capazes de algum distanciamento mesmo em relação à nossa paixão predominante.

A consciência intelectual exige que o agente cognitivo só dê seu assentimento a crenças que dispõem de fundamentação racional. Nós vimos que a posição de Nietzsche exclui esta possibilidade, pois ele concorda em linhas gerais com o diagnóstico que Pascal oferece de nossa condição epistêmica: embora o ceticismo epistemológico seja irrefutável, ele não coíbe os mecanismos naturais de formação de crenças nem enfraquece nossa adesão instintiva aos primeiros princípios. Nietzsche recusa as conclusões apologéticas que Pascal pretende extrair deste diagnóstico mediante a mobilização de um contra-argumento poderoso: a tese de que o erro é uma condição de existência. O próprio Pascal oferece a Nietzsche elementos para uma radicalização da posição cética nesta direção, ao insistir na tese de que o argumento da incerteza de nossa origem compromete a confiabilidade 
Lopes, R.

epistêmica de nossa adesão instintiva aos princípios. Nietzsche converte este argumento em uma objeção à defesa pragmática da antropologia cristã apresentada por Pascal:

O erro capital de Pascal: ele pretende provar que o cristianismo é verdadeiro porque ele é necessário - isto pressupõe que existe uma providência boa e verdadeira, que faz com que tudo o que é necessário seja também verdadeiro: poderia haver, entretanto, erros necessários! E, afinal de contas, a necessidade poderia apenas aparecer como tal, pois já estamos tão acostumados ao erro, que ele acabou se tornando imperativo, como uma segunda natureza (Nachlass/FP 7 [233], 1880, KSA 9.366).

Esta passagem nos revela que Nietzsche estava consciente das peculiaridades da estratégia apologética montada por Pascal ${ }^{48}$. Aqui ele faz referência direta ao argumento pragmático utilizado pelo jansenista para justificar a adesão ao mito da queda: sua adoção exige o sacrifício do intelecto, mas sem ele o homem se torna um paradoxo para si mesmo ${ }^{49}$. A réplica de Nietzsche ao argumento

48 Este nem sempre é o caso. Há um tipo de objeção que Nietzsche formula contra o uso apologético do ceticismo por Pascal que nos induz a crer que ele estava pensando em um algo como a estratégia fideísta, pois o alvo é justamente o fato de que uma defesa da fé mediante a restrição do uso da razão deixa indeterminado o conteúdo da fé que deveria ocupar o lugar deixado vazio pela razão. Esta objeção é válida apenas em relação ao uso defensivo das crenças mediante a exposição da incapacidade demonstrativa da razão (Nachlass/FP 7 [34], 1880-81, KSA 9.325). Embora essa objeção não se aplique ao uso instrumental do ceticismo por Pascal (que envolve uma estratégia bem mais complexa, como vimos na reconstrução oferecida na seção II do presente artigo), penso que ela é procedente em relação ao uso polêmico da razão feito por Kant para a defesa indireta da legitimidade, por parte do agente moral, de seguir aderindo ao que ele chama de fé moral (sobre isso, $c f$. Lopes, 2008, capítulo II, seção 3.3-3.4).

49 Pascal apresenta este argumento como um desdobramento de sua discussão sobre o ceticismo pirrônico no fragmento LA 131 (434). Em uma nota póstuma de 1887, Nietzsche remete a uma passagem deste fragmento. Mas ele o faz já sob a influência da leitura de F. Brunetière, que propõe que a visão de mundo de Pascal seja identificada com o pessimismo e não com o pirronismo. A nota de Nietzsche retoma esta discussão e propõe um paralelo entre Pascal e Schopenhauer, o que é uma constante nas notas deste período: "Segundo Pascal, sem a fé cristã, nós, assim como a natureza e a história, nos tornamos un monstre et un chaos. Nós cumprimos essa profecia. Depois do débil e otimista século XVIII ter embelezado e racionalizado os seres humanos. Schopenhauer e Pascal: em um sentido essencial, Schopenhauer foi o primeiro a retomar o movimento de Pascal: un monstre et un chaos, por conseguinte, algo que deve ser negado... História, natureza, o próprio ser humano! Nossa incapacidade de conhecer a verdade é a o resultado de nossa corrupção, de nossa queda moral:

172 | Cad. Nietzsche, Guarulhos/Porto Seguro, v.38, n.3, p. 125-180, setembro/dezembro, 2017. 
recorre subliminarmente à posição de Descartes: sem o pressuposto de um deus veraz, que faça a necessidade coincidir com a verdade, não estamos autorizados a confiar em nenhum argumento de tipo pragmático:

Não se faz justiça a Descartes quando se qualifica de leviano seu apelo à credibilidade de Deus. De fato, apenas sob a suposição de um deus que seja moralmente igual a nós a verdade. e a busca da verdade é algo que, de antemão, promete êxito e faz sentido. Uma vez que este Deus esteja descartado, cabe perguntar se o ser enganado não pertenceria às condições de vida (Nachlass/FP 36 [30], 1884-85, KSA 11.563).

Aqui, como em diversas outras ocasiões, Nietzsche reafirma a disjunção entre o útil e o verdadeiro. A vida não vale como argumento, pois entre suas condições está o erro. Teorias falsas podem a princípio explicar infinitamente mais do que teorias verdadeiras. Além disso, o hábito é tão forte que faz as vezes da natureza: se nos habituamos aos erros, eles se tornam condições de possibilidade da experiência. $\mathrm{O}$ argumento de que sem eles um determinado âmbito da experiência se torna impensável prova apenas que eles são necessários para que a experiência continue a ser pensada segundo certos parâmetros tradicionais, que foram incorporados ao nosso patrimônio genético e por isso se tornaram "irrefutáveis". Pascal dificilmente contestaria a correção destas objeções. A princípio não há nada que nos garanta que a condição humana possa fazer sentido, ou tenha que fazer sentido. Mas quem não quer renunciar a esta expectativa deveria adotar uma posição similar à de Descartes. Infelizmente ela é incerta. Mas se não o fosse, ela certamente não seria inútil.

Marco Brusotti, autor de um estudo que explora de forma exaustiva todos os aspectos e nuances do projeto nietzschiano de

assim pensa Pascal. E também, no fundo, Schopenhauer. 'Quanto mais profunda a corrupção da razão, tanto mais necessária a doutrina da salvação' - ou, em termos schopenhauerianos, a negação" (Nachlass/FP 9 [182], 1887-88, KSA 12.445).

Cad. Nietzsche, Guarulhos/Porto Seguro, v.38, n.3, p. 125-180, setembro/dezembro, 2017. $\mid 173$ 
Lopes, R.

converter a paixão do conhecimento em uma estética da existência nas obras do período intermediário, deve por justiça ter a última palavra em relação a este debate. Ele destacou com clareza impar que no final de sua trilogia sobre o espírito livre, Nietzsche se vê obrigado a recorrer à arte como um contrapeso ao compromisso com a integridade intelectual ${ }^{50}$. A paixão do conhecimento exige duplamente a arte: ela fornece ao filósofo o modelo mais adequado para o pleno desenvolvimento daquilo que Stendhal denominou de processo de cristalização, sem o qual nenhuma grande paixão é capaz de se impor $^{51}$; e é graças à sua inspiração que o filósofo é capaz de recuperar a boa consciência no eterno jogo das aparências. E justamente esta boa consciência no jogo das aparências é o requisito necessário para o conhecimento, pois este é apenas uma das muitas modalidades desta dança dos viventes. $\mathrm{O}$ conhecimento não se opõe à arte e à aparência, mas é uma de suas diversas manifestações. Não devemos, entretanto, concluir que Nietzsche fechou sobre si mesmo um círculo, retornando à metafísica de artista de sua juventude. A arte está agora decididamente no pólo da aparência. Por seu intermédio nenhuma porta é aberta para a um tipo de experiência ou atividade que se possa qualificar como metafisicamente diferenciada. Além disso, a

50 Cf. Brusotti, 1997, pp. 438-452.

51 A filosofia se inspira na arte na medida em que ela se propõe como tarefa criar uma forma de vida caracterizada pela paixão do conhecimento. Toda paixão é paixão pelo belo, e toda beleza é uma promessa de felicidade. Portanto, cabe à filosofia um embelezamento da ciência. Este é o tema do aforismo 427 de Aurora, intitulado "O embelezamento da ciência": "Tal como surgiu a jardinagem rococó, do sentimento de que "a natureza é feia, enfadonha, selvagem - vamos embelezá-la (embellir la nature!)" -, sempre torna a surgir, do sentimento de que "a ciência é feia, seca, desconsolada, morosa, difícil - vamos embelezá-la!", algo que se denomina filosofia. Ela quer o que querem todas as artes e criações - sobretudo entreter: mas quer isso, conforme o seu orgulho herdado, de um modo mais sublime e elevado, diante de espíritos seletos. Criar para esses uma arte de jardins cujo encanto maior, como naquela "mais vulgar", seja a ilusão visual (com templos, vistas panorâmicas, grutas, cascatas, labirintos, para usar imagens); apresentar a ciência numa amostra e com toda espécie de iluminações maravilhosas e súbitas, e nela misturar tanta indeterminação, desrazão e devaneio que se possa nela passear "como na natureza selvagem", mas sem esforço e tédio - isso não é ambição pouca: quem a tem sonha até mesmo em assim tornar dispensável a religião, que para os homens de outrora foi a suprema espécie de arte do entretenimento" (M/A 427 3.263, tradução de PCS).

174| Cad. Nietzsche, Guarulhos/Porto Seguro, v.38, n.3, p. 125-180, setembro/dezembro, 2017. 
arte assume agora uma tarefa que parece estar subordinada aos fins da vida filosófica: ela deve fornecer um contrapeso à integridade intelectual, não apenas para evitar uma recaída na moralidade, como tem sido tradicionalmente destacado, mas também para evitar que nos tornemos reféns do domínio tirânico de uma única paixão:

Nossa última gratidão para com a arte. - Se não tivéssemos aprovado as artes e inventado essa espécie de culto do não-verdadeiro, a percepção da inverdade e mendacidade geral, que agora nos é dada pela ciência - da ilusão e do erro como condições da existência cognoscente e sensível -, seria intolerável para nós. A integridade intelectual teria por conseqüência a náusea e o suicídio. Mas agora a nossa integridade intelectual tem uma potência contrária, que nos ajuda a evitar tais conseqüências: a arte, como a boa vontade para a aparência. Não proibimos sempre que os nossos olhos arredondem, terminem o poema, por assim dizer: e então não é mais a eterna imperfeição, que carregamos pelo rio do vir a ser - então cremos carregar uma deusa e ficamos orgulhosos e infantis com tal serviço. Como fenômeno estético a existência ainda nos é suportável, e por meio da arte nos são dados olhos e mãos e, sobretudo, boa consciência, para poder fazer de nós mesmos um tal fenômeno. Ocasionalmente precisamos descansar de nós mesmos, olhando-nos de cima e de longe e, de uma artística distância, rindo de nós mesmos ou chorando por nós; precisamos descobrir o herói e também o tolo que há em nossa paixão do conhecimento, precisamos nos alegrar com a nossa estupidez de vez em quando, para poder continuar nos alegrando com a nossa sabedoria! E justamente por sermos, no fundo, homens pesados e sérios, e antes pesos do que homens, nada nos faz tanto bem como o chapéu de bobo: necessitamos de toda arte exuberante, flutuante, dançante, zombeteira, infantil e venturosa, para não perdermos a liberdade de pairar acima das coisas, que o nosso ideal exige de nós. Seria para nós um retrocesso cair totalmente na moral, justamente com a nossa suscetível integridade intelectual, e, por causa das severas exigências que aí fazemos a nós mesmos, tornarmo-nos virtuosos monstros e espantalhos. Devemos também poder ficar acima da moral: e não só ficar em pé, com a angustiada rigidez de quem receia escorregar e cair a todo instante, mas também flutuar e brincar acima dela! Como poderíamos então nos privar da arte, assim como do tolo? - E, enquanto vocês tiverem alguma vergonha de si mesmos, não pertencerão ainda a nós! (FW/GC 107, KSA 3.464, tradução de PCS, com alterações). 
Lopes, R.

A hegemonia inconteste de uma única virtude (mesmo quando ela é descrita em termos de paixão) é também uma forma de tirania. Espera-se do filósofo que ele seja capaz de escapar deste jugo tirânico, tornando-se senhor de suas próprias virtudes. Este preceito vale também para as virtudes intelectuais. A Gaia Ciência, a começar pelo título, anuncia um distanciamento da seriedade típica da alma dominada pela paixão. Do projeto de conferir uma dimensão heróica ao moderno ethos científico resultou uma série de registros literários que são como que instantâneos de uma interioridade filosófica em contínua experimentação consigo mesma. No final deste percurso Nietzsche já não acredita que seja possível um confronto com o cristianismo via paixão do conhecimento. A eterna comédia do conhecimento não gera na alma uma tensão similar à produzida pelo cristianismo de Pascal. A busca do conhecimento no horizonte do ceticismo exige muita renúncia, mas não é capaz de gerar um novo orgulho. A preservação da integridade intelectual confere ao filósofo uma vantagem frente ao cristão, mas ela é relativa e o coloca na iminência de uma recaída na moralidade. Nietzsche reconhece a necessidade de lhe impor limites. $\mathrm{O}$ aparente fracasso destes experimentos o levou a adotar uma estratégia mais audaciosa de confrontação com o cristianismo e com a visão moral de mundo, o que fez com que ele se distanciasse ainda mais da agenda filosófica inspirada em Montaigne. A necessidade de um confronto no campo especulativo já é plenamente reconhecida em A Gaia Ciência. O louco que anuncia a morte de Deus, no aforismo 125, e o demônio que comunica a doutrina do eterno retorno no aforismo 341, são duas máscaras literárias que revelam certo pudor de Nietzsche de se apresentar diretamente ao leitor na qualidade de intérprete, profeta e redentor da cultura ocidental em bloco. Mas o acirramento da disputa com o cristianismo e com a moral cristã nas obras subsequentes fará com que ele perca esse resquício de pudor. No calor da disputa, Nietzsche muitas vezes nos comunica a impressão de ter se esquecido de uma de suas tantas advertências,

$176 \mid$ Cad. Nietzsche, Guarulhos/Porto Seguro, v.38, n.3, p. 125-180, setembro/dezembro, 2017. 
a de que a exceção nunca deve querer se converter em regra. Nós, leitores, devemos estar atentos a isso.

Philosophy as a way of life: confronting modern Skepticism Abstract: The aim of this paper is to show that the way in which Pascal reacts to Montaigne's attempt of recovering the ancient conception of philosophy as a way of life by reworking certain elements he borrowed from the sceptical tradition will have considerable impact on the similar philosophical project Nietzsche tries to develop in his so-called middle period works (section III of this paper). Nietzsche's starting point is the diagnosis that the crisis of Christianity in early Modern Europe did not make room for the development of a contemplative life emancipated from religious illusions. Instead of that, it was followed by the degradation, not to say the complete suppression of contemplative life and the immersion in modern activism (see CS 359, BGE 58). The trilogy Nietzsche dedicated to the Free Spirits is an attempt of directly counteracting this tendency and regaining a non-religious sense of contemplative life in the most unlikely context of the bourgeois society of the second half of the Nineteenth Century. I intend to show that by the time of publishing Daybreak, Pascal becomes his most stimulating opponent. Before doing it, I reconstruct the way Montaigne receives and transforms the heritage of ancient scepticism (section I) and, thereafter, I proceed to investigate how Pascal reacts to the revival of ancient scepticism, putting special emphasis on the way he tries to undermine the ideal of a contemplative life freed from the tutelage of Christianity, a philosophical project which had in Montagne its most consequent representative (section II).

Keywords: skepticism - contemplative life - Montaigne - Pascal - intellectual integrity 
Lopes, R.

\section{Referências bibliográficas}

ABEL, G. Nietzsche: die Dynamik der Willen zur Macht und die ewige Wiederkehr. Berlin/New York: Walter de Gruyter, 1998.

BACON, F. Novum Organon. Trad. José Aluysio Reis de Andrade. São Paulo: Abril Cultural, 1973.

BRAHAMI, F. Le Scepticisme de Montaigne. Paris: PUF, 1997. . Le Travail du scepticisme: Montaigne, Bayle, Hume. Paris: PUF, 2001.

BRUNETIÈRE, F. Études critiques sur l.histoire de la littérature française. Troisième série. Paris: Hachette et C.ie, 1887.

BRUSOTTI, M. Die Leidenschaft der Erkenntnis. Philosophie und ästhetische Lebensgestaltung bei Nietzsche von Morgenröthe bis Also Sprach Zaratustra. Berlin:

de Gruyter, 1997.

CICERO, M. T. Akademische Abhandlungen. Luculus (Lateinisch-Deutsch). Text und Übersetzung von Christoph Schäublin. Einleitung von Andreas Graeser und Christoph Schäublin. Hamburg: Felix Meiner Verlag, 1995.

DESCARTES, R. Oeuvres (edição de Adam \& Tannery em 11 vols.). Paris: J. Vrin, 1996.

. Discurso do Método. In: Os pensadores. Trad. J. Guinsburg e Bento

Prado Júnior. São Paulo: Nova Cultural, 1991. . Meditações sobre Filosofia primeira. Trad. Fausto Castilho.

Campinas: Ed. Unicamp, 2004.

GIOCANTI, S. Penser l.irrésolution: Montaigne, Pascal, La Mothe le Vayer. trois itinéraires sceptiques. Paris: Honoré Champion, 2001.

LOPES, Rogério. Ceticismo e Vida Contemplativa em Nietzsche. Belo Horizonte: UFMG, 2008.

178 | Cad. Nietzsche, Guarulhos/Porto Seguro, v.38, n.3, p. 125-180, setembro/dezembro, 2017. 
Filosofia como forma de vida: o embate com o ceticismo moderno

MAIA NETO, J. R. Hume and Pascal: Pyrrhonism vs Nature. In: Hume Studies, vol. 17, n. 01, 1991, pp. 41-49.

. The Christianization of Pyrrhonism: Scepticism and Faith in Pascal, Kierkegaard, and Shestov. Dordrecht/Boston/London: Kluwer Academic Publishers, 1995.

. Academic's Scepticism in Early Modern Philosophy. In: Journal of History of Ideas 58, 2 (1997), pp. 199-220.

MILL, John Stuard. O Utilitarismo. Trad. Alexandre Braga Massella. São Paulo: Iluminuras, 2000.

MONTAiGNE, M. Ensaios (03 vols.). Trad. Rosemary Costhek Abílio. São Paulo:

Martins Fontes, 2000/2001.

. Essais. Ed. P. Villey et V.-L. Saulnier. Paris: PUF, 1988.

MONTINARI, M. Nietzsche lesen. Berlin/New York: Walter de Gruyter, 1982.

NIETZSCHE, F. Sämtliche Werke. Kritische Studienausgabe (= KSA: 15 vols.). Hrsg. von G. Colli und M. Montinari. Berlin/New York: de Gruyter, 1988.

. A Gaia Ciência. Trad. Paulo César de Souza. São Paulo: Companhia das Letras, 2001.

. Aurora. Trad. Paulo César de Souza. São Paulo: Companhia das Letras, 2004.

PASCAL, B. Gedanken, Fragmente und Briefe. Aus dem Französischen nach der mit vielen unedirten Abschnitten vermehrten Ausgabe P. Faugère.s. Deutsch von Dr. C. F. Schwartz. (edição em dois volumes). Leipzig: O. Wigand, 1865.

. Oeuvres Complètes. Préface d.Henri Gouhier. Présentation et notes de Louis Lafuma. Paris: Éditions du Seuil, 1963.

. Pensamentos. Trad. Mario Laranjeira. São Paulo: Martins Fontes, 2001.

SEXTUS EMPIRICUS. Grundriss der Pyrrhonischen Skepsis. Einleitung und Übersetzung von M. Hossenfelder. Frankfurt am Main: Suhrkamp Verlag, 1968.

PIPPIN, R. Nietzsche moraliste français. Paris: Odile Jacob, 2006.

Cad. Nietzsche, Guarulhos/Porto Seguro, v.38, n.3, p. 125-180, setembro/dezembro, 2017. $\mid 179$ 
Lopes, R.

POPKIN, R. H. História do Ceticismo: de Erasmo a Spinoza. Rio de Janeiro: Francisco Alves, 2000.

. Ceticismo (textos organizados por E. Eigenheer). Niterói: Eduff, 1996.

STENDHAL. De l.Amour. Paris: G-Flammarion, 1965.

VIVARELLI, V. Montaigne und der .Freie Geist.. In: NS 23, 1994, 79-101. . Nietzsche und die Masken des freien Geistes: Montaigne, Pascal und Sterne. Würzburg: Könnigshausen \& Neumann, 1998.

Artigo recebido para publicação em 09/03/2017 Artigo aceito para publicação em 25/08/2017

$180 \mid$ Cad. Nietzsche, Guarulhos/Porto Seguro, v.38, n.3, p. 125-180, setembro/dezembro, 2017. 